\title{
A BASIC INCOME FOR ALL? UNDERSTANDING THE BASIC INCOME CONCEPT FROM THE PERSPECTIVES OF COMMUNITY-BASED ADVOCATES
}

by

Andrew Silverthorn, BSW, Ryerson University, 2016

\author{
An MRP \\ presented to Ryerson University \\ in partial fulfillment of the \\ requirements for the degree of \\ Master of Social Work \\ in the Program of \\ Social Work
}

Toronto, Ontario, Canada, 2017

(C) Andrew Silverthorn 2017 


\section{AUTHOR'S DECLARATION FOR ELECTRONIC SUBMISSION OF A MRP}

I hereby declare that I am the sole author of this MRP. This is a true copy of the MRP, including any required final revisions.

I authorize Ryerson University to lend this MRP to other institutions or individuals for the purpose of scholarly research

I further authorize Ryerson University to reproduce this MRP by photocopying or by other means, in total or in part, at the request of other institutions or individuals for the purpose of scholarly research.

I understand that my MRP may be made electronically available to the public. 


\begin{abstract}
A Basic Income for All? Understanding the Concept of a Basic Income from the Perspectives of Community-based Advocates

Master of Social Work, 2017

Andrew Silverthorn

Program of Social Work, Ryerson University
\end{abstract}

Basic income is a policy concept that has garnered considerable research attention over the past decade. However, very few studies have explored the concept from the perspectives of frontline service providers and anti-poverty activists. Grounded in structural social work and intersectionality theories, this qualitative study centres the insights of six individuals working and organizing in various community roles, including frontline social workers and grassroots anti-poverty activists. The findings from this study, gathered through a focus group, suggest that community responders to poverty are deeply unhappy with the current welfare state, possess mixed feelings about the possibilities of a basic income strategy, and are highly skeptical about the ethical implications and political motivations behind the Ontario government's basic income pilot study. It is hoped that the findings from this research will complicate and deepen perspectives on a basic income while simultaneously contributing to the momentum behind this emerging policy intervention. 


\section{ACKNOWLEDGEMENTS}

There are many people with whom this research project would not have happened without.

I would like to thank my research supervisor, Dr. Susan Preston, for her ongoing feedback, encouragement, and overall guidance. Your enthusiasm and patience made this process feel possible.

Thank you to Tara and Adrienne for keeping me grounded throughout this journey. Your willingness to always making space for my anxieties, frustrations, and success stories throughout this experience was appreciated more than you know. Additionally, thank you to Taggart and Lois for always checking-in and being dependable in your compassion and support.

A big thank you to everyone at Meal Exchange who introduced me to the world of basic income research. Some of my greatest learnings came from our time together.

Lastly, I would like to express my sincere gratitude to the research participants who devoted a very rainy evening in May to discuss the ins and outs of a basic income. Bruce, Joy, Lucy, Dale, Catherine, and Ella, thank you for all your thoughtful and critical insights. Your knowledge was vital to this project becoming a reality. Thank you. 


\section{DEDICATION}

For my mother,

who is the hardest working and most resilient person I will ever know...

and

For Jamie,

for being my "day one” and always believing in me, even when I haven't. 


\section{TABLE OF CONTENTS}

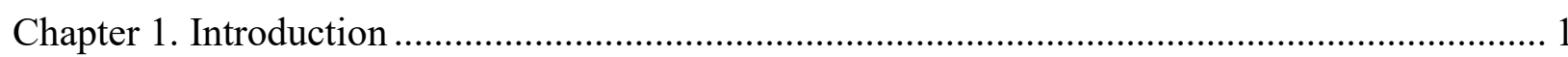

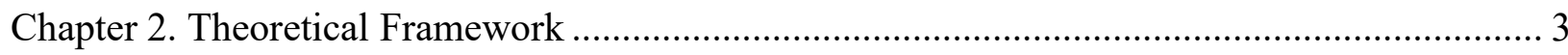

Positioning Myself Within the Research ................................................................... 3

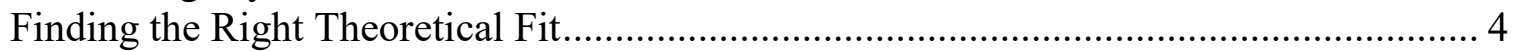

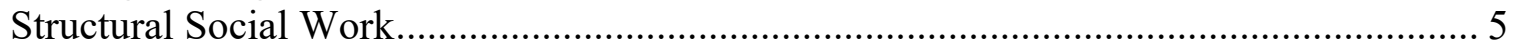

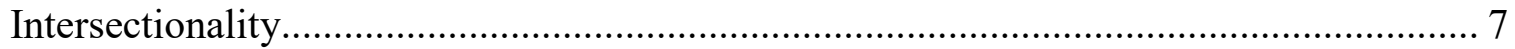

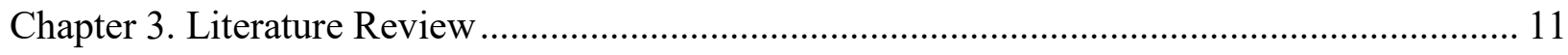

Poverty in Ontario: A Brief Overview ................................................................... 11

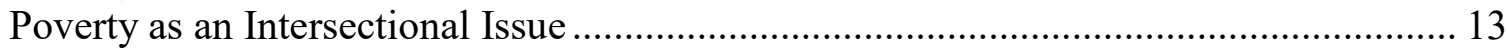

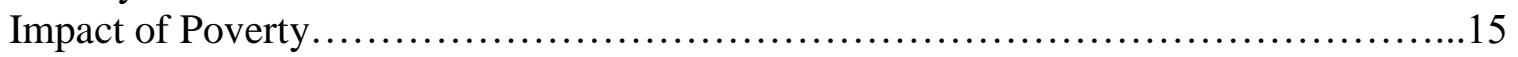

Current Responses to Poverty............................................ 15

The Basic Income Approach................................................................................... 17

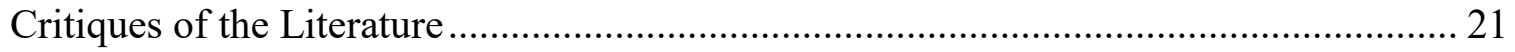

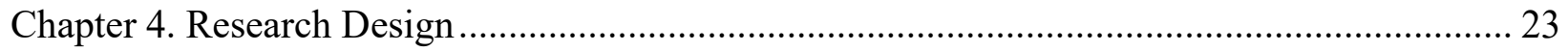

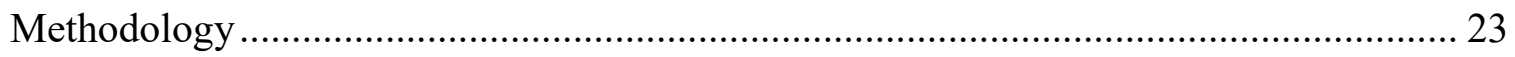

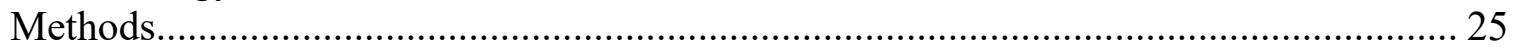

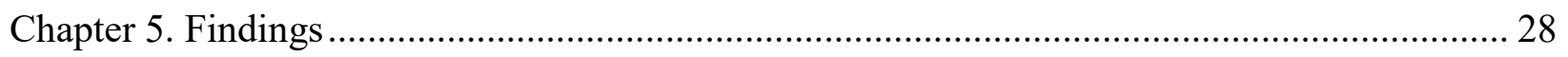

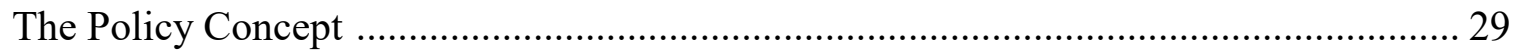

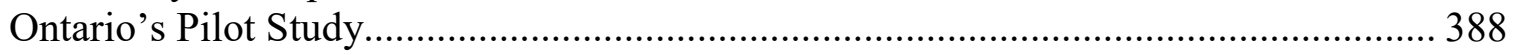

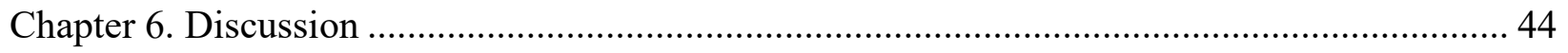

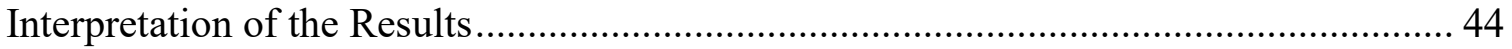

Implications for Service Users, Practitioners, and Policymakers .................................. 52

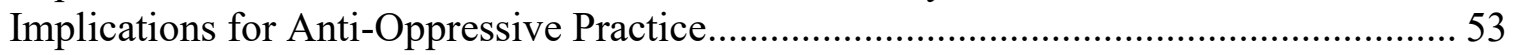

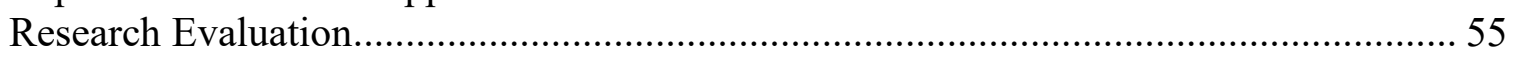

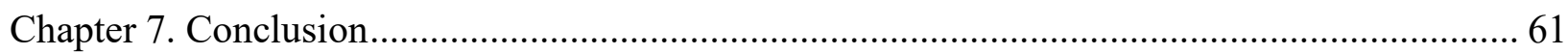

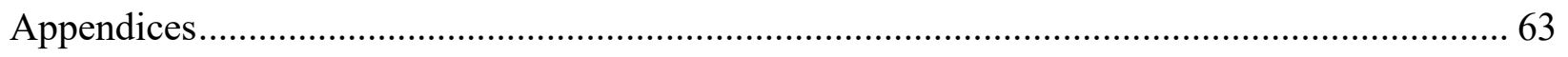

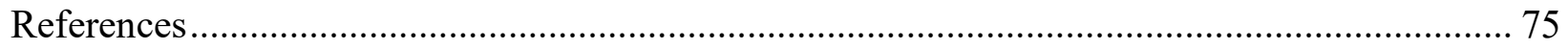




\section{LIST OF APPENDICES}

Appendix A - Recruitment E-mail

Page 63

Appendix B - Social Media Recruitment Text

Page 65

Appendix C - Social Media Recruitment Image

Page 66

Appendix D - Consent Form

Page 67

Appendix E - Focus Group Interview Guide

Page 71

Appendix F - Research Ethics Board Approval

Page 74 


\section{Chapter 1. Introduction}

Basic income, commonly understood as a generous form of social security where all citizens receive a base income via an unconditional government cash transfer (Van Parijs, 1995), is a concept that has gained considerable attention within the past several years. In 2016, the provincial government of Ontario announced their plans to conduct a basic income pilot study (Ontario Ministry of Community Services, 2016) while the province of Prince Edward Island unanimously passed a motion to pursue launching a joint basic income pilot study with the federal government (Prince Edward Island Legislative Assembly, 2017). Outside of Canada, many other pilot studies have been announced while a select few have also been launched. Despite a rapidly growing body of literature on the topic, very few academic or communitybased studies have looked at the concept of a basic income from the perspectives of frontline service providers, anti-poverty activists, and labour rights advocates. For the research that does exist, basic income is often promoted as a silver bullet to poverty. Considering the growing political and social interest in a basic income, in addition to the resurgence in academic interest on the topic, the need for exploring more nuanced and critical perspectives has become apparent.

The aim of this research paper was to undercover, explore, and centre emerging views on a basic income that lay outside of the dominant public health and social policy discourse and research. To accomplish this, I turned to those involved in the trenches of poverty, namely frontline service providers and grassroots anti-poverty activists. In centering these views, my hope was not to reject or delegitimize the momentum behind a basic income, but rather to better understand its potential for contributing to anti-oppressive practice and transformative social change. 
The following chapters will detail the above research process. In Chapter Two, the theoretical framework of the project will be explored and explained. Chapter Three will summarize relevant research from Canada on a basic income, while Chapter Four will detail the research design, including the methodology and methods of the project. Chapter Five will present original qualitative findings collected through a focus group, while Chapter Six will present a discussion linking the existing literature to the findings of this research project. Lastly, Chapter Seven will present a set of concluding thoughts, including areas for ongoing research in relation to a basic income. 


\section{Chapter 2. Theoretical Framework}

The following chapter details the chosen theories that informed the theoretical framework of this research project. In addition, this chapter explores my own positionalities as a researcher and how my socio-economic identities and histories will have inevitably influenced this project.

\section{Positioning Myself Within the Research}

Research is never neutral. As Bourke (2014) noted, a researcher's biases will inarguably influence a research project from beginning to end. According to Baskin (2016), Western approaches to research often lack an acknowledgement of researchers' identities and biases while these are often made explicit in studies conducted by Indigenous researchers. Therefore, in an attempt to decolonize my research process, I will break away from Western traditions and draw from the self-identification practices of Indigenous scholars.

I am a white, cisgender, able-bodied, male individual who is university-educated. I also identify as queer, working class, and someone who has been a consumer of social services. As an adolescent, I was supported by a single-mother who worked in low-wage, low-skilled, and precarious jobs that lacked benefits. I am the youngest of three siblings but the first to complete a university degree. I now possess a sizeable student debt that will be with me for many years to come. I have never received social assistance benefits. As a young adult, I attempted to access social assistance but was denied due to strict eligibility criteria that have since been amended. Lastly, I currently reside in Toronto, the traditional territories of the Anishinaabe, Mississaugas, and Haudenosaunee Peoples, while I grew up in rural Ontario on the traditional lands of the Anishinaabe, Odawa, and Ojibwe Peoples.

Poverty, income inequality, and their impacts are issues that speak deeply to me. I view capitalism as a major force behind many historical and ongoing forms of oppressions. These 
oppressions include but are not limited to: colonization, slavery, labour exploitation, food insecurity, homelessness, various health inequities, and some forms of sexism, racism, and ableism. In addition, I also view capitalism as a driving force behind interconnected phenomena that influence and accelerate oppression, such as environmental destruction, globalization, and neoliberalism. I am primarily interested in who does and does not benefit from capitalism, how capitalism is overtly and covertly perpetuated, what conditions lead to social and economic mobility, and how to remedy the inequalities that have resulted from capitalism.

\section{Finding the Right Theoretical Fit}

Understanding and analyzing poverty, income inequality, and policy responses to these multiplex issues requires a unique mix of theoretical perspectives. As Harris (2001) argued, while critiques of income distribution may indeed influence political change, other intersecting forces have the potential to produce outcomes that are both unstable and unpredictable. Considering this, it is my belief that interventions to poverty cannot be conceptualized or analyzed through a lone theoretical orientation.

Much of the present social work literature is informed by theories that fall under the umbrellas of post-structuralism and postmodernism. As Caputo, Epstein, Stoesz, and Thyer (2015) noted, postmodernism has been endorsed by several social work journals, in addition to being incorporated into the accreditation standards of many social work programs. I prescribe to many of these philosophical assumptions myself. However, Pease (as cited in Weinberg, 2008) raised an important concern that postmodernism's emphasis on micro-interactions may result in a failure to recognize material oppression and unequal access to resources. This concern speaks loudly to me as someone who has often witnessed a lack of analysis concerning class and 
poverty in literature, education, and community spaces that operate from a place of postmodernism.

Considering the tensions discussed above, I have decided to adopt elements from two theoretical orientations to draw on the strengths of each. From structuralism I will adopt the theory of structural social work and from postmodernism I will adopt the theory of intersectionality. In doing so, I hope to reflect the systemic social, economic, and political barriers that feed poverty and the unequal distribution of income while also reflecting how oppression and privilege rooted in history greatly impact material wellbeing. I acknowledge that by adopting both these theories I risk doing neither justice. Yet, I have attempted to do so anyway in an attempt to bring a level analysis to basic income research I have yet to encounter.

\section{Structural Social Work}

According to Healy (2005), the earliest reference to structural social work can be traced to Middleman and Goldberg, both American social work scholars, who published Social Service Delivery: A Structural Approach to Social Work Practice in 1974. Since then, Canadian social work scholars Maurice Moreau, Ben Carniol, and Bob Mullaly have been heavily influential in further developing this practice theory. At its core, structural social work operates from an understanding that individual circumstances are the result of a person's social and economic position within society (Lundy, 2004) and that discrimination based on identity is inherent to the present social order (Mullaly, 2007). By adopting this stance, structural social work resists blaming individuals for their life circumstances by seeking to transform oppressive social structures as opposed to the individuals oppressed by those structures (Lundy, 2004; Mullaly, 2007). In addition, structural social work aims to move beyond a redistributive model of social justice. Instead, it works towards a social justice model that "transforms the entire constellations 
of oppressive rules, processes, and practices" (Mullaly, 2007, p. 284), thereby creating meaningful and long-term social equality.

Although heavily informed by Marxist and feminist analyses of exploitation and exclusion, structural social work asserts that all forms of oppression are equally devastating and worthy of attention (Moreau, 1989; Mullaly, 2007). However, the approach also recognizes that all forms of oppression are unique, therefore requiring equally unique responses (Mullaly, 2007).

Structural social work is particularly well suited for analyzing poverty with its focus on capitalism, socio-economics and politics (Weinberg, 2008). In addition, structural social work's emphasis on "how the rich and powerful within society constrain and define the less powerful" (Martin, 2003 as cited in Healy, 2005) is equally fitting. As a result, the theory lends itself nicely to advocating for state interventions to material and economic oppression.

There are several significant criticisms of structural social work. Weinberg (2008) summarized these criticisms as: viewing human beings as being separate from structures, lacking an analysis for contradictions of social location within social groups, viewing power as a commodity, creating a dualism between micro and macro practice, and undertheorizing the agency of individuals. I have attempted to remedy these shortcomings in several ways, including coupling structural social work with intersectionality and recruiting participants with lived experiences of poverty or those who provide them with frontline services. In doing so, I hope to position individuals as part of structures, unearth some contradictions within social groups, and support the agency of individuals living in poverty and those who provide them support at a micro practice level. 


\section{Intersectionality}

Intersectionality was first developed and employed as a theory and analytic tool by legal scholar Kimberlé Crenshaw. Informed by Black feminism and Critical Race Theory, Crenshaw created this theory to address the marginalization of Black women within antidiscrimination law and feminist and anti-racist politics (Carbado, Crenshaw, Mays, \& Tomlinson, 2013). Later, Crenshaw employed the theory to highlight how violence against women advocacy lacked an analysis for the unique challenges faced by women of colour. In both projects, Crenshaw centred the ongoing forms of marginalization within institutionalized discourses such as law, while simultaneously highlighting how discourses of resistance, such as feminism and anti-racism, could also reproduce marginalization by excluding the experiences of people with multiple oppressed identities. Since then, intersectionality has been widely adopted throughout the social science disciplines with notable authors such as Patricia Hill Collins (2015) making important contributions to the theory.

In its simplest form, intersectionality is the "assertion that social identity categories such as race, gender, class, sexuality and ability are interconnected and operate simultaneously to produce experiences of both privilege and oppression" (Smooth, 2013, p. 11). According to McCall (2005), there are three unique approaches to intersectionality: anti-categorical, intracategorical, and inter-categorical.

On one end of the continuum, the anti-categorical approach attempts to challenge "the singularity, separateness, and wholeness" (McCall, 2005, p. 1778) of social categories. In other words, this approach questions the existence and use of normative and fixed forms of social categorization based on the belief that categorization leads to exclusion and marginalization. In the middle of the spectrum is the intra-categorical approach. This approach involves an 
examination of the overlapping experiences of disadvantage within the same social group.

Lastly, on the other end of the spectrum, the inter-categorical approach forwards an analysis based on social categories to examine inequities that exist across two or more social groups. As McCall noted, this approach can be highly complex with the addition of each sub-category. For example, an inter-categorical investigation of inequality experienced among women could result in an analysis that explores each possible combination of race, class, (dis)ability, and sexuality among women identified individuals.

For the purposes of this research study, I primarily adopted an inter-categorical approach. In keeping with McCall's spectrum of intersectional complexity, the primary social group this project looked to investigate was individuals living on low-incomes in Ontario. When possible, I attempted to centre, compare, and contrast the unique experiences of racialized and nonracialized low-income individuals according to the literature available and participants' responses. However, it is important to highlight that due to the complexity and level of commitment needed to fully map out all the inter-categorical possibilities, that a complete intercategorical analysis would not be realistic within a single research article (McCall, 2005). As a result, the literature review, findings, and discussion sections are not fully consistent in maintaining an inter-categorical analysis.

As with structural social work, several critiques concerning intersectionality have been discussed in the literature. According to Nash (2008), these "unexplored paradoxes" (p. 4) include intersectionality lacking a clear methodology, essentialising black women and their individual experiences, not having scholarly consensus and consistency if both marginalized and privileged subjectivities are included, and being ambiguous in its definition. It is important to 
note that Nash stated that the intention behind these critiques was not motivated by a desire to do away with intersectionality, but rather as a way to fill critical gaps within the theory itself.

Due to the scope of this project, there is a serious limitation in bringing together both structural social work and intersectional analyses. Mainly, this project maintains a narrow view of oppression by highlighting the challenges faced by low-income Ontarian without also exploring their experiences of privilege. For example, this project does not explore how the potential economic liberation of low-income Ontarians will continue to be implicated in globalization, including environment destruction and the exploitation of cheap labour in the Global South. Therefore, for the purposes of this study, intersectionality is understood to be the experience of multiple oppressed identities as opposed to both oppressed and privileged. As a result, the two theories feed into their shared criticism of perpetuating grand narratives.

Unfortunately, some of the other criticisms will also be evident throughout this research project. As structural social work theory is focused on broader socio-economic categories, essentialising through grand narratives was unavoidable. Additionally, due the limited scope of this project, there are indeed methodological gaps in how intersectionality was applied. However, as structural social work was the main theory employed throughout this research project, my hope was that the strengths of an intersectional analysis would remedy the gaps of structural social work while at the time outweighing its own shortcomings.

As discussed previously, poverty is simply too complex to analyze through any single theoretical framework. For the purposes of this research project, structural social work contributed a grounding and wide critique of capitalism, politics, and systems of exploitation and oppression. To deepen this critique, intersectionality contributed a more nuanced analysis of these same issues, highlighting, when possible, the interlocking experiences of those impacted by 
both poverty and other experiences of marginalization. Together, these theories guided the research study from beginning to end and significantly contributed to the evaluation of the overall project. 


\section{Chapter 3. Literature Review}

Basic income in a policy concept that has existed for many decades. As of late, the concept has gained renewed attention thanks to policy researchers, advocacy group members, politicians, and business leaders across Canada and the world who have shown considerable support for a basic income in their respective localities. This literature review summarizes the Canadian research on a basic income, drawing from Ontario specific sources where possible. In addition, relevant findings related to poverty, employment, and social security are explored.

\section{Poverty in Ontario: A Brief Overview}

Understanding poverty in a provincial or national context is a complicated and serious challenge. At present, Canada lacks both an official measurement and definition of poverty (Parliament of Canada, Library of Parliament, 2008). Currently, Statistics Canada employs three different measurements of low-income which include the low-income cut-offs (LICOs), the market basket measure (MBM), and the low-income measurement (LIM). However, since there is no universally agreed upon definition of poverty in Canada, these measurements are not considered to be appropriate indicators of poverty (Statistics Canada, 2016). However, the LIM appears to the measurement of choice when discussing a basic income in Ontario (see Segal, 2016). As a result, this paper will draw on this measurement.

According to the most recent low-income measure after tax (LIM-AT) calculation, approximately $13.8 \%$ of Ontario's population were low-income in 2014 (Statistics Canada, n.d.). During the same year, $11.9 \%$ of households in the province experienced some form of food 
insecurity $^{1}$ (Tarasuk, Mitchell, \& Dachner, 2016). In 2011, almost one-quarter (23.5\%) of households were also living in unaffordable housing ${ }^{2}$ (Canadian Housing and Mortgage Corporation, n.d.a).

Homelessness. In Canada, the task of estimating the number of people experiencing homelessness has been an ongoing source of debate (Gaetz, Donaldson, Richter, \& Gulliver, 2013). However, shelter use data from the federal Homelessness Partnering Secretariat does provide some insight. According to the most recent national numbers, approximately 450,000 people used an emergency shelter between 2010 and 2014 (Employment and Social Development Canada, 2016). Unfortunately, the most recent numbers do not list any province/territory specific data.

Un(der)employment. Labour market statistics paint a similar story. At the beginning of 2017, approximately $6.4 \%$ of the province's working population was unemployed (Statistics Canada, 2017a). This has been the lowest recorded unemployment rate since 2012. However, this success rate should be viewed with caution considering that most jobs created in the previous year were part-time (Statistics Canada, 2017b). This reality reflects the increase in

1 'Household food insecurity' is defined as when a household has "inadequate or insecure access to food because of financial constraints" (Tarasuk, Mitchell, \& Dachner, 2016, p. 2).

${ }^{2}$ Housing is considerable affordable when the accommodation's "costs account for less than 30 per cent of before-tax household income" (Canadian Housing and Mortgage Corporation, n.d.b, para. 3) 
underemployment ${ }^{3}$. Although Statistics Canada does not capture full numbers on

underemployment, the Canadian Labour Congress (2014) estimated that between 2008 and 2013, almost three-quarters $(72 \%)$ of net jobs created were characterized as positions resulting in underemployment. Therefore, despite relatively low unemployment compared to recent years, the quality and stability of new jobs remains lacking.

\section{Poverty as an Intersectional Issue}

Poverty is not experienced equally between or within social groups. In summarizing the findings from numerous studies conducted by the Canadian Centre for Policy Alternatives (CCPA), Jamasi (2016) stated that "We have identified a high share of people in poverty to be young people, women, racialized persons, recent immigrants and persons who aren't in an economic family" (p. 28). Other Canadian studies and organizations have confirmed these findings (Campaign 2000, 2016; Canadian Women's Foundation, 2017; Employment and Social Development Canada, 2012).

Indigenous communities in Canada are disproportionately impacted by poverty. When compared to non-Indigenous populations, studies have shown Indigenous Peoples to experience devastatingly high levels of food insecurity (Tarasuk, Mitchell, \& Dachner, 2016) and emergency shelter use (Employment and Social Development Canada, 2016). Furthermore, when median incomes are compared, Indigenous Peoples earn 30\% less than non-Indigenous peoples (Wilson \& MacDonald, 2010). These findings are important as they shed light on the ongoing

3 'Underemployment' is defined as having “an unmet need for paid employment" (Canadian Labour Congress, 2014, p.2) 
legacy of Canada's colonial history. As indicated by these statistics, Indigenous Peoples continue to be largely excluded by the social and economic systems of this country.

Likewise, racialized communities and immigrants also experience disproportionately high levels of poverty. According to Employment and Social Development Canada (2012), racialized people experience a poverty rate $13 \%$ higher than non-racialized people, with $66 \%$ of racialized persons living in poverty also being immigrants. When compared to all racial groups, Black communities are the hardest hit, experiencing the highest rates of household food insecurity (Tarasuk, Mitchell, \& Dachner, 2016) and unemployment (Block \& Galabuzi, 2011) in the country.

The layering of intersectional identities can often compound experiences of poverty. For example, using data from Statistics Canada, a report from the Canadian Women's Foundation (2017) estimated that $36 \%$ of First Nations women living off reserve and 23\% of Métis and Inuit women living in the provinces were low-income. The same report put the rates of poverty for visible minority women and women living with disabilities at $28 \%$ and $33 \%$, respectively.

The statistics are equally concerning on the labour front. According to research by Block and Galabuzi (2011), racialized men and women are $24 \%$ and $48 \%$ more likely to be unemployed when compared to their non-racialized counterparts. For first generation immigrants, many also struggle with a significant pay gap. Whereas first generation men earn approximately 68.7 cents for every dollar earned by non-racialized men, first generation women earn even less at 48.7 cents for every dollar earned by non-racialized men. For racialized refugee and immigrant women in Ontario, they experience a unique nexus of challenges, struggling with precarious work, intergenerational cycles of poverty, and barriers to entering their original 
professions (Ng et al., 2016). Clearly, gender, (dis)ability, race, and immigration history can all greatly compound one's experience of poverty.

\section{Impacts of Poverty}

Poverty has serious implications for social, health, and economic outcomes. Research has shown that food insecurity related to inadequate financial resources has been linked to nutritional inadequacies (Kirkpatrick \& Tarasuk, 2008), diabetes (Gucciardi, Vogt, DeMelo, \& Stewart, 2009), suicidal ideation (Davison, Marshal-Fabien, \& Tecson, 2015), and overall poor health among children (Kirkpatrick, McIntyre, \& Potestio, 2010).

Such outcomes have had serious impacts on the healthcare system. A recent estimate suggested that depending on the severity of food insecurity, that healthcare costs were $16 \%$ to $76 \%$ higher for food insecure households than for food secure one's (Tarasuk et al., 2015). Such findings are important in that they illustrate the interconnected relationships between poverty, negative health outcomes, and increased government expenditures on healthcare. In other words, poverty is costly to everyone.

\section{Current Responses to Poverty}

In Canada, including most other industrialized nations, there are two primary responses to poverty. The first response is government administered cash transfers, including tax benefits, pensions, and social assistance programs. The second response is in-kind services, including social housing, food banks, and other charitable responses. These services are delivered by a variety of organized groups, including multiple levels of government, community-based organizations, and private charities (Mulvale, 2008). Together, these responses form what is known as the social security system. However, as Mulvale (2008) argued, 'system' may not be an appropriate word due to the often complicated and uncoordinated nature of these responses. 
In Ontario, research has shown that the current social assistance programs are ineffective, punitive, and Draconian in nature. For example, research on the current social assistance model of springing recipients back into the labour market showed that up to $50 \%$ of recipients who leave social assistance for work later return to the program (Lightman, Mitchell, \& Herd, 2007) and that the jobs recipients leave for are often low-paying and precarious in nature (Evans, 2007). Colour of Poverty - Colour of Change (2011), a provincial-wide campaign of organizations and individuals, also found that racialized social assistance recipients often struggled with "difficult, unhelpful or even adversarial" (p.4) caseworkers who perpetuated experiences of belittlement, stigmatization, and lack of mistrust.

In addition to the above realities, social assistance rates in the province continue to be deplorably low. Currently, a single person on social assistance can either receive a monthly cash transfer of $\$ 1128$ from the Ontario Disability Support Program (ODSP) (Ontario Disability Support Program Act, 1997) or $\$ 706$ from Ontario Works (OW) (Ontario Works Act, 1997). A couple with two children can receive up to $\$ 1821$ or $\$ 1205$ per month depending on the respective program. These rates have resulted in social assistance recipients experiencing a dramatic gap between social assistance rates and the poverty line (Tiessen, 2016).

Responses from charitable and in-kind initiatives also have proven to be ineffective. Multiple studies on food banks and meal programs in Ontario concluded that the quality and suitability of food made available to service users was typically substandard (Tarasuk \& Eakin, 2003; Tarasuk \& Eakin, 2005; Dachner, Gaetz, Poland, \& Tarasuk, 2009; Tarasuk \& Dachner, 2009). In addition, studies have shown that food bank work, much like social assistance case work, also involved considerable surveillance. Gatekeeping practices such as means-testing, catchment areas, and income reviews were found to be commonplace (Tarasuk et al., 2014). Yet, 
after being approved, service users continued to be the subjects of governmentality through limitations to the frequency and amount of food they were permitted to collect (Tarasuk \& Eakin, 2003). While a full analysis of these programs is beyond this research project, it is clear from the literature that neither government nor community level responses have adequately addressed the needs of those living in poverty.

\section{The Basic Income Approach}

Often referred to as a guaranteed annual income or universal income, the concept of a basic income (BI) has gained renewed attention as of late. With separate pilot studies recently announced by the provincial governments of Ontario and Prince Edward Island, the concept of a BI has now re-entered the public consciousness as a more effective method for addressing poverty.

Definition. The concept of a basic income (BI) is relatively simple. Leading advocate Philippe Van Parijs defined BI as an unconditional grant "paid for by a political community to all its members on an individual basis, without means test or work requirement" (Van Parijs, 2004, p. 8). According to Van Parijs (1995), the term basic is not meant to communicate notions of basic needs, but rather convey that the grant is a basis for which other incomes may be added. Despite considerable debate about how a BI should be implemented, Cantillion and MacLean (2016) argued that most proposals draw on the same characteristics. These characteristics include that the grant should be universal, unconditional, without means-testing, and allocated to individuals as opposed to entire household units.

Despite the common characteristics shared by most BI models, theorists and researchers have spent a considerable amount of time debating on how the benefit should be delivered to its 
recipients. The two most common methods discussed in the literature are a negative income tax and a universal demogrant. These models are discussed below.

Negative income tax (NIT) model. American economist Milton Friedman is often credited with popularizing the NIT model. In the book Capitalism and Freedom, Friedman and Friedman (2002) explained the NIT model as a partial top-up tied to income earnings. According to Friedman, there are three different scenarios for how the NIT could be administered: (a) individuals with an income above a set amount would not receive the subsidy and would pay a tax, (b) individuals with an income below the set amount would receive half of the subsidy rate that would bring their incomes closer to the taxable rate, and (c) individuals with no income would receive a full subsidy and pay no tax.

Friedman's model was based on the assumption that poverty alleviation efforts reduce "the incentives of those helped to help themselves" (Friedman \& Friedman, 2002, p. 192) and that a NIT should not top up incomes to a standard fixed amount. Due to this, Raventós (2007) argued that a NIT should not be considered a basic income model as it violates the universal and unconditional nature of the concept.

Universal demogrant (UD) model. Van Parijs (2004) argued for a much different delivery method. In the UD model, a basic income would be paid to all individuals regardless of their level of income. Such a scheme would eliminate means-testing and, unlike current social assistance programs and income supplements, would not be contingent on an individual's willingness to work or their previous tax contributions.

One argument against this model is the distribution of public money to the economic elite. Van Parijs (2004) argued that this concern should be outweighed by the benefits that would arise from a ubiquitous grant, including widespread awareness of entitlement rights, evaporation 
of stigma and humiliation associated with receiving social assistance, and increased stability with transitioning to employment without the reduction or revocation of the grant.

Basic income as a remedy to poverty-related outcomes. Many social science, public policy, and health researchers from Canada have studied the effectiveness of a basic income for improving poverty related outcomes. These improvements include reduced food insecurity (Emery, Fleisch, \& McIntyre, 2013; Tarasuk, 2017) lower mortality rates (Emery \& Matheson, 2012; Nelson \& Fritzell, 2014), fewer hospitalizations (Forget, 2013), and overall improved physical and mental health (McIntyre, Dutton, Kwok, \& Emery, 2016).

Feminist scholars have theorized several ways in which they believe women will also benefit from a BI. These benefits include greater financial autonomy and stability, compensation for under/unpaid care work, and improved psychological wellbeing due to increased feelings of personal autonomy (Cantillon \& McLean, 2016; Eglarte, 2008). However, unlike the previous studies discussed, little data exists to tangibly support these claims, signifying the need for more research in this area.

Labour vs. basic income? Harvey (2008) stated that there are two popular camps among welfare state reformists, namely those who advocate for a guaranteed income and those who advocate for guaranteed employment. The guaranteed income perspective is most in line with the goals of a basic income, while the employment perspective stems from the belief that the most effective way to address poverty is by strengthening the existing welfare model through the creation of more job opportunities financed by government stimulus. These differing perspectives bring to light an important tension, especially for those concerned with labour rights and economic mobility. 
In a review of labour union publications from Canada, Vanderborght (2006) found that labour organizers viewed BI with considerable caution. Prime among unionists' concerns were that a BI could be antithetical to goals of the labour movement by undermining minimum wage policies and reinforcing neoliberalism. However, Vanderborght's (2006) research is not clear on how the labour groups studied believed a BI could perpetuate and strengthen neoliberalism. More recently, the Ontario Public Service Employees Union [OPSEU] (2017) stated concerns over the inclusion of administrative costs as a measure of analysis in Ontario's basic income pilot study. In their position statement on a basic income, the union questioned the motivates behind the desire to study administrative costs, signaling that these results could be used to justify future reductions in the number of frontline social assistance workers. As a result, the union stated that poverty reduction should not come at the cost of frontline public service jobs and that cutting these jobs will contribute to neoliberal efforts to shrink the welfare state.

Financial viability of a BI. Several Canadian researchers have attempted to estimate the national cost of a basic income according to numerous interpretations of the models discussed above. For simplicity's sake, I have only reported on the estimates for a universal model.

Using a policy simulator from Statistics Canada, Macdonald (2016) estimated the cost of several basic income variations. Their findings found that universal model would cost the federal government $\$ 31.5$ billion, requiring taxes to increase by $14 \%$. As a result, the study argued against implanting such a model.

Findings from Broadway, Cuff, and Koebel (2016) suggest a different outcome. According to their findings, a revenue-neutral universal transfer of $\$ 20,000 /$ year to adult citizens could be put into place with a small deficient of $\$ 0.59$ billion if existing federal and provincial transfers were eliminated. 
In a separate model proposed by Stevens and Simpson (2016), they advocated for funding a basic income through the elimination of a series of non-refundable and refundable tax credits that largely exclude low-income earners. Under this model, adults 18 and older would receive a basic income, ranging from $\$ 6,700$ to $\$ 17,727$, depending on family size and income. As the income levels of recipients increased, the value of their basic income transfer would be reduced accordingly until they reached an income threshold where they were no longer eligible. Although the authors referred to this model a "universal basic income guarantee", the design significantly mirrors a negative income tax scheme.

Critiques of the pilot study. Several anti-poverty advocacy groups have critiqued Ontario's basic income pilot study. Clark (2016), speaking on behalf of the Ontario Coalition Against Poverty (OCAP), raised concerns around that belief that governments would "redistribute wealth, reduce poverty and decrease the exploitative capacity of the capitalists" (para. 9). The Put Food in the Budget Campaign (Balkwill, 2016) and Canadian Union of Public Employees [CUPE] (2017) raised additional concerns, stating the pilot study was a government stall tactic to avoid increasing the current social assistance rates. Such critiques shed important light on more critical perspectives of a BI that much of the academic literature and recent media coverage have lacked.

\section{Critiques of the Literature}

Despite the range and rigor of research concerning a basic income, the current literature suffers from several gaps.

From my perspective as a social worker, the lack of knowledge generated from frontline workers who work to alleviate poverty is concerning. Even more worrisome is how few voices with a lived experience of poverty are included. As a basic income has the potential to 
dramatically change both the nature of social work and the lives of those living in poverty, these voices are crucial to the conversation. This gap also reflects the lack of qualitative research concerning a basic income. Across both the academic and grey literature, quantitative studies dominant the Canadian BI scholarship (see Forget, 2013; MacDonald, 2016; McIntyre, Kwok, Emery, \& Dutton, 2016, Tarasuk, 2017) As a result, there has been little room for subjugated dialogues and knowledge generated outside of positivist methods.

In addition to the above, the basic income literature has lacked an intersectional lens. As noted previously, poverty is an intersectional issue, and yet little has been written on how a basic income might interact with other interlocking systems of oppression. A handful of authors (Eglarte, 2008; Cantillon \& McLean, 2016; Macdonald, 2016) have discussed how a basic income might affect women and various age groups, but outside of these efforts, little has been done to explore other experiences of oppression or intersectional experiences of oppression.

Lastly, much of the literature lacks an analysis of a basic income's potential impact on the labour market and the changing nature of work. Specifically, little has been discussed about the support given to a basic income by business and technology leaders involved with automation and artificial intelligence. Considering these reflections, the basic income literature has missed a vital opportunity to explore this policy as part of an inevitable transition away from a society based on the production of goods and the monetization of labour.

In order the fill the previously mentioned methodological and theoretical gaps, this research project was guided by the question: "What are the opinions and perspectives of frontline service providers' regarding the appropriateness and effectiveness of a basic income for reducing poverty, income inequality, and the associated impacts of neoliberalism for the province's most economically marginalized?". 


\section{Chapter 4. Research Design}

According to Kothari (1990), research methodology is defined as "the logic behind the methods" (p. 8). Whereas research methods are the techniques employed by the investigator to conduct the research, Kothari stated that research methodologies communicate the various assumptions and rationales underlying these techniques. As the terms methodology and method are often used interchangeably in academia, I have included Kothari's definitions to clarify what I mean when I use each of these terms.

\section{Methodology}

Selecting a specific qualitative methodology for this project proved challenging. As Thorne, Reimer Kirkham, and MacDonald-Emes (1997) argued, the common qualitative methodologies, such as phenomenology, grounded theory, and ethnography, originated from academic disciplines with their own unique histories, worldviews, and research practices. As methodologies rooted in the traditions of philosophy, sociology, and anthropology, the researcher who wishes to explore a question outside of the parameters of these disciplines may find themselves at an impasse. In reviewing the literature, none of the existing qualitative methodologies appeared compatible with my research question and design. This most likely reflects that quantitative methods, such as surveys, are often employed to gather and analyze opinions (Creswell, 2014). Considering this dilemma, I chose to employ a generic qualitative research methodology.

Merriam (1988) explained that generic qualitative research studies are studies that "simply seek to discover and understand a phenomenon, a process, or the perspectives and worldviews of the people involved" (p. 11). Building upon this definition, Caelli, Ray, and Mill (2003) clarified that generic qualitative studies either combine several existing methodologies or 
claim no methodological stance at all. In reviewing the literature, I could not find a

methodological approach that was concerned with uncovering, centering, and analyzing research participants' opinions about a specific topic or concept. This gap in methodology was the impetus for adopting a generic qualitative approach.

In keeping with Kothari's assertion that methodology is the logic behind the methods, I developed a logic framework based on a series of assumptions and beliefs. These assumptions and beliefs include the following: achieving social justice requires a greater focus on economic and political research (Dempsey, 2008), frontline workers have the capacity to meaningfully question societal structures and the status quo (Rountree \& Pomeroy, 2010), and discussion among a group of people close to an issue can produce inter-subjective opinions that reflect the beliefs of that group (Acocella, 2012). By making these beliefs explicit, my intension is to still claim a methodological stance while at the same time honouring that none of the existing methodologies were the right for this research project.

To date, one similar study has been conducted and published in Canada. In this study, Mulvale (2008) employed a qualitative design without explicitly stating a methodological approach. The goal of this study was to "sound out current interest in BI among those experiencing poverty and those who advocate on their behalf" (p. 13). Three focus groups were held across Saskatchewan, with participants including both individuals living in poverty and anti-poverty activists. The data collected from the focus groups was then organized into six parent themes that included additional sub themes. In discussing the limitations of the study, Mulvale noted that the findings could not be generalized across Saskatchewan or Canada. This limitation demonstrated the need for Ontario-specific research. Furthermore, as Mulvale's article 
was published in Canadian Social Work, this suggested to me that generic qualitative research is considered as both acceptable and valuable within the landscape of social work research.

\section{Methods}

Recruitment and sampling. For the purposes of this study, I recruited frontline service providers engaged in poverty alleviation/reduction and/or anti-poverty activism. The term frontline service providers was defined as individuals holding professional titles such as social worker, nurse, or dietician, and individuals involved in community-based advocacy and organizing. This broad definition was informed by the belief that advocacy and activism, whether paid or unpaid, formal or informal, are vital forms of frontline community work. By adopting a wider and more inclusive definition of frontline service provider, my intention was to resist the professionalizing of community work (Fitzsimons, 2010) and to honour that many individuals do community work without formal credentials and degrees.

Participants were recruited through the nonprobability technique of purposive sampling. Faulkner and Faulkner (2014) defined this sampling method as "simply selecting a sample on the basis of one's knowledge of a population" (p. 80). This was accomplished by sending out recruitment advertisements through social media groups, publically available e-mail addresses, and newsletters affiliated with anti-poverty, income security, labour rights, and health promotion. In addition, I also recruited through my own social and professional networks.

Overall, eight participants were recruited while six attended the actual focus group. Two of the participants were involved in grassroots anti-poverty groups, with one of these participants openly sharing that they were a social assistance recipient. Three of the participants were employed in traditional frontline positions, including housing, community health, and employment services. An additional participant was employed in a community advocacy role. 
All of the formally employed frontline providers were involved in anti-poverty activism in either formal or informal capacities. Lastly, all the participants were in bodies that could be read as white/of European ancestry.

Participants received a ten-dollar gift card and two transit tokens as compensation for their participation.

Data collection. Data was collected via an audio-recorded focus group. This method was chosen based on the overlap of two previously mentioned methodological assumptions, namely that through group discussion frontline service providers can question societal structures (Rountree \& Pomeroy, 2010), and produce inter-subjective opinions that reflect their collective beliefs (Acocella, 2012). The focus group lasted for approximately 90 minutes. Participants were asked a variety of open-ended questions such as: "Theoretically, what kind of impact do you think a basic income could have on poverty reduction in Ontario?", "Who would and would not benefit from a basic income?" and "How do you see a basic income impacting low-income communities that also struggle with other issues such as racism?". The audio-recording was then transcribed verbatim. All identifying information was excluded from the transcript, including the names of organizations and groups that participants were affiliated with. Participants were also given pseudonyms there were used throughout the transcript and subsequent findings section.

Data analysis. According to Rabiee (2004), focus groups often generate so much data that both novice and experienced researchers can become overwhelmed. Drawing on the work of Krueger (1994) and Kreuger and Casey (2000), Rabiee developed an approach to focus group data analysis that is simple, structured, and flexible. This approach includes the following steps: skilfully facilitating the group interview to generate rich data; familiarization with the data through listening to the recording and reading through the transcript multiple times; identifying a 
thematic framework by developing initial short phrases and ideas; indexing the data to shift and refine themes; and lifting quotes and applying them to their appropriate thematic headings.

In addition to the above, Rabiee also recommended regularly revisiting the research question to ensure that the project's purpose drives the analysis. This was achieved by ensuring the research question was made visible on all documents related to analysis.

In working from a generic qualitative approach, this research project drew from a variety of research techniques and methods. By adopting a set of assumptions and beliefs, recruiting through purposive sampling, employing a focus group as the data collection method, and analyzing the data according to Rabiee's flexible yet structured approach, I believe both myself and the participants were free to go wherever the data wanted to go. However, due to this highly fluid research process, this study may also have experience some significant methodological gaps. This will be explored further in the discussion chapter and should be taken into consideration when reviewing the findings in the following chapter. 


\section{Chapter 5. Findings}

The findings for this section are broken down into two sub-sections: The Policy Concept and Ontario's Pilot Study. My initial plan did not involve such clear-cut distinctions. However, after conducting the focus group it became clear that the views of frontline service providers concerning the provincial government's basic income pilot study offered a rich terrain for exploring the disconnects between frontline work and policy development processes.

Although studying this disconnect was not a component of my original research question, allowing participants to use the pilot study as an analogue to explore the implications of this theoretical policy was crucial for drawing out conversations related to the research question that may otherwise have not occurred. By making the time and space to discuss the pilot study, participants utilized the available information on the pilot as a reference point to think through and discuss the challenges, complexities, and subtleties associated with addressing poverty and how a basic income may or may not address these domains. As a result, I believe that discussing the pilot study was fundamental to answering the question "What are the opinions and perspectives of frontline service providers regarding the appropriateness and effectiveness of a basic income for reducing poverty, income inequality, and the associated impacts of neoliberalism for the province's most economically marginalized?"

To utilize the full breadth and depth of knowledge shared by participants, the policy concept section will discuss the participants' theoretical considerations related to a basic income while the pilot study section will explore the participants' reflections on the research, policy development process, and politics of the Ontario government's basic income pilot study. 


\section{The Policy Concept}

While discussions of the provincial government's pilot study dominated much of the conversation, focus group participants shared many theoretical reflections about the concept of a basic income. The themes that emerged from these reflections fell under one of the following themes: the pervasiveness and persistence of economic inequality, the social complexities of poverty, and limited effectiveness and appropriateness. Sub-themes that emerged from these larger umbrella themes will be discussed below.

The pervasiveness and persistence of economic inequality. Several participants shared reflections on a basic income in relation to the current realities of capitalism, namely the pervasiveness and persistence of economic inequality. Among these reflections, precariousness, technological displacement, and neoliberalism emerged as major themes.

Precariousness. Participants expressed concerns about the precariousness of the current labour market and the potential impact of a basic income. Speaking on the quality of new jobs openings, Lucy, a member of a grassroots anti-poverty campaign, stated that "in this day and age, everything is part-time and precarious." Ella, a housing worker, shared similar reflections about the precariousness of the job market for new graduates, stating that regardless of the quality or stability of the job that "there's also this push and pull with the labour market where you should feel so fortunate that you even get a job.”

Despite a basic income often being promoted as a remedy to precarious employment, Dale, also a member of an anti-poverty community group, raised concerns over this framing. As he shared: "It's an actual wage top up that's going to the employers...[and] this notion of actually creating a precedent of paying workers' wages out of the general tax revenue is, I think, very dangerous." Later, Dale expanded on this perspective, stating that "I think if something along the 
lines of what they're planning to introduce is introduced on a society-wide basis, the main factor is going to be actually the depressing of wages."

It is important to note that since this focus group, the Ontario government announced a plan to increase the province's minimum wage to $\$ 15.00$ an hour by 2019 . However, Dale's analysis still holds considerable merit as increasing the minimum wage does not guarantee profit-driven employers will create full-time permanent positions. By finding evolving ways to push low-skilled, low-waged, and newly qualified workers out of the labour market, some employers may continue to shift the responsibility of providing adequate incomes onto governments through the introduction of a basic income that includes wage top-ups for earners who lack full-time permanent positions.

Technological displacement. Tied to precariousness was concern about technological displacement. Joy, a community advocacy worker, was particularly vocal about technological displacement:

I'm going to talk about robots now because they're coming! And they're coming for us! I do think we need to start preparing for like a post-work economy and what we're going to be doing when robots are going to be doing quite a lot of our work. And how are we going to not just live but live with dignity and be able to explore the things we want to explore, you know, not just as people living in poverty, working day-to-day.

Despite an increasing number business and technology leaders endorsing a basic income, Dale expressed doubt over the benevolence of these business elites:

I mean, I agree that technological displacement is a huge threat and I think we've got to challenge it. But I don't think it's in a capitalist society that this is a problem...I mean, the 
way competition works amongst business is they use technological displacement to cut costs and displace workers and to get more out of the workers that they keep...

This dialogue unearthed participants' views on capitalism as an economic system weaponized to insure its continued survival and dominance. As forwarded by both Joy and Dale, capitalism was viewed as inherently adaptable to technological change in a manner that continues to maximize profit, concentrate wealth, and perpetuate inequality. Upon analysis, this discussion presented an important consideration to me, namely if capitalism will merely adapt to a basic income as it has to technological change and, in the process, neutralize the benefits of basic income.

Neoliberalism. Participants also shared many reflections related to neoliberalism. For Catherine, as someone who provided education and employment services to low-income women, she expressed concerns over the possibility of cut backs in healthcare and social services due to a basic income:

...the fear about the whole basic income is that they'll use it as an excuse to get rid of social services that are needed. Whether it's healthcare or whether it's whatever. They're going to say, 'Oh, well you can afford it now.' That is really my fear about what is going to happen.

Later in the conversation, Catherine shared a story about why her fears of neoliberalism were so strong. Speaking about a public basic income consultations held in her community by the provincial government, she stated:

Well, we had a consultation in [community name] and there was a lot of conservative MPs and, even though it's federal, came because we're a very conservative area. And they all agreed with basic income, and once they started talking about it I really...I really felt 
like, 'Oh, this is not good.' Because they did talk about streamlining services, reducing government workers, cutting government costs for social services, blah, blah, blah... Sharing her experiences working with OW and ODSP recipients, Joy raised that neoliberal restructuring is already well underway. Discussing a recent shift in social assistance delivery, Joy explained:

...they've been doing office changes where they've been removing peoples' workers and going back to a team approach and it's not been...we've had so many problems at the place that I work with people not being able to access the things that they need because they don't have a worker anymore.

Interestingly, focus group participants often communicated about the value and necessity of social assistance case workers. Yet, many also discussed the moral policing and surveillance implicit to these roles. These conflicting viewpoints point to the complexities of current social assistance case work, namely that frontline providers exist in a climate where they must enact neoliberal policies that simultaneously hamper their own professional capacities and commitments to social change. This tension has important implications for social workers involved in a social assistance delivery, namely what value will their positions hold to both the provincial government and social assistance recipients should the current system be replaced by a more generous basic income.

Other participants, such as Bruce, a social worker employed in a community health role, expressed concern over the political malleability of a basic income. Discussing the policy concept, Bruce called it a "nebulous idea supported by both social progressives and fiscal conservatives, which means it could be just about anything." With basic income increasingly discussed as an agenda item that can unite both the political right and left, Bruce's comments 
spoke to the need to interrogate political motivates and remain ever vigilant about the perniciousness of neoliberalism. Bruce was not alone in this analysis. As Dale shared: ...neoliberalism is not going to go away anytime soon, so we've got to...we've got to prepare for it. And there's sort of notion that there's an end run around to the problem and I think that that's a mistake on our side 'cause I don't think it exists.

Dale returned several times to sharing his skepticism over what he referred to as social policy end-run to neoliberalism and poverty. This reflection brought forward an important question that I posed to the participants later on: is a basic income simply a capitalist solution to the problem of capitalism? Several participants nodded in response to this, indicating that they viewed a basic income as a capitalist solution. Joy verbally shared her thoughts, stating "I agree that capitalism is really the honest problem, for sure. And um...yeah. I don't think we can rely on people's benevolence...". From this dialogue, a larger and unanswered question emerged regarding the effectiveness of social policy for creating significant and meaningful change. This will be explored further in the discussion chapter.

The social complexities of poverty. Despite my best intentions, intersectionality was an underexplored theme throughout the focus group. I primarily attribute this to my own shortcomings as a researcher. My additive use of intersectionality as a complement to structural social work as opposed to an elemental anchoring point unfolded throughout several aspects of the research project but was especially prominent during the focus group. However, several participants did share insightful reflections on the multi-directional relationship between poverty and social marginalization. Among the group, Ella was particularly vocal that increased incomes could not solve all social issues. During a discussion on the complexity of oppressions faced by low-income groups, Ella shared that: 
I think that, again, money doesn't fix everything. Money's not going to fix racism or the experience of racism. Could it help someone who maybe didn't have an opportunity to further their education based on their social class? I believe it might. Right? But sexism, homophobia, racism, all those things, some of those are embedded beliefs that people have, right?

Later, Ella built upon this analysis by reflecting on the relationship between access to quality education and economic mobility for Indigenous Peoples:

We know in Indigenous communities that access to education is not the same. It's not the same in the classroom; it's not the same in terms of quality of the quality of school you're getting. You have to fly to a different community in order to access school, right? So that's not going to...that needs to also be looked at as well, right? So, if you're going to a certain school where you don't have the same access...money's not going to fix that. So...it intersects.

Coming from a labour market perspective, Joy shared similar insights regarding the connections between employment, poverty, and racism. As she shared, "And if we're already seeing people with specific last names being discriminated against by employers...getting access to education isn't going to change that kind of employer feeling, right?"

These comments alluded to an important yet unnamed belief among the group that racialized communities face poverty and highly stratified levels of income inequality not because of individual or community-wide deficits, but rather due to systemic experiences of racism. Such a finding is crucial to reflect on when considering the universal, one-size fits all approach to poverty and precarious employment that a basic income proposes. 
Participants also expressed concern about the diversity of the pilot study's sampling pools and questioned how this would impact the pilot's outcomes data. Speaking on the communities selected to be involved in the pilot, Bruce said, "I don't know how effective, like if Hamilton is their benchmark for diversity, I'm not sure how well they can really assess that in the pilot. But I don't even think the program can address poverty let alone racism." In response, Ella questioned why Toronto, as the province's most diverse city, had not been selected as a pilot site, demonstrating the importance of understanding poverty and policy interventions from an intersectional lens.

These reflections on diversity highlight an important limitation in solely understanding poverty through a lens of Marxian economics. Clearly, as shown by the participants' comments on the social complexities of living on a low-income, multiple systems of oppression can and do exacerbate the experience of poverty.

Limited appropriateness and effectiveness. The focus group participants had many mixed feelings and reflections regarding the appropriateness and effectiveness of a basic income for reducing poverty. This was evident throughout the duration of the conversation as support for the concept ebbed and flowed depending on the person speaking and the question being discussed.

Despite her displeasure with the basic income model proposed in the pilot study, Ella reflected on the short-term positive impacts that the increased rates could have on her service users' lives:

I'm thinking about when I work with folks that are living in market-rent apartments receiving ODSP, and then they live off of $\$ 200$ for the rest of the month somehow. Um...and then...how much of a difference that this would make...[to] improve their 
quality of life and how that intersects with their mental health and/or their substance use...

However, Ella also reinforced her overall lack of faith in the basic income model proposed by the pilot study, stating that "the long-term isn't...the poverty piece isn't there." Both Joy and Catherine stated similar sentiments, sharing that they supported the concept of a basic income but not the model proposed by the provincial government's pilot study.

Throughout the focus group, participants often returned to speaking about the need for complementary and integrated services targeted towards low-income populations in order to strengthen the effectiveness of a basic income. Increases in the minimum wage, affordable housing stock, public transit systems, and mental health and addiction services, in addition to introducing universal child and pharma-care, were highlighted as particularly important. The need for increased regulation of market prices for essential necessities, such as housing and food, also was discussed.

For Bruce, the idea that a basic income should offer a flat rate to all recipients seemed like an ineffective and "very market-based approach." He went on to discuss the concept of a guaranteed services approach where necessities, such as housing and medications, could be guaranteed to low-income individuals. Ella agreed with this approach, stating that "more money doesn't decrease wait times. In fact, people might just go to the private sector and then try to find, you know, a private therapist or...obviously a market rent apartment." Later, Ella shared further thoughts on the need to invest in more services to ensure access to resources for future generations:

I just wonder...like what if they took this money and instead put it in building affordable housing and more access to mental health services and substance use addiction 
services...dental care, universal child care. Like this money and the rates that they're raising at that level, which I know you could never do because it's ever revolving, and then investing that, which then has a long-term impact on generations of people to come, right?

Joy had similar thoughts on the need for a mixed-approach response, challenging the notion that a basic income could be "a panacea that can just replace everything." Likewise, Catherine discussed the need for greater flexibility within the province's financial assistance program for post-secondary students, sharing a story on how the low-income women she worked with were often ineligible for financial aid from being in default. Such reflections, as coming from frontline providers, add an important perspective with much of the basic income literature authored by public health and social policy academics who seldom discuss the need for an integrated approach that includes both a basic income and the strengthening of existing supports.

Drawing from a more future oriented analysis, Lucy wondered if a basic income could eventually lead to even greater income inequality and poverty:

So, there's a fight for minimum wage and there's a fight for basic income. Blah, blah, blah. And all of it is kind of mute in the end if it comes down to everyone gets this minimum basic wage that's below the line of poverty. So, now you are creating two very distinct levels of poor and not-poor, right? So, it eliminates all those middle deservingundeserving quibbling all about that. And you just have this line of people, the main popularity is all getting this basic income, basically, that's below the line of poverty. Is this what we're looking at for the future?

Bruce echoed this, reminding the group that "It's sort of the elephant in the room that like we can talk about all the details and the specific conditions, but at the end of the day what we're talking 
about is we're still keeping people poor." From these comments, it was clear that many

participants viewed a basic income, and particularly the model proposed by the provincial government's pilot study, as a momentary fix to the ever-evolving problem of material inequality inherit to capitalist society.

\section{Ontario's Pilot Study}

As previously stated, discussions of the provincial government's pilot study dominated much of the focus group. Participants expressed a range of frustration, disappointment, skepticism, and confusion throughout these conversations. Many also expressed significant concerns over the research design and process. These concerns included the following themes: ethical and moral issues; communication and transparency; and congruence between theory and design. Political motivations behind the pilot study also emerged as major theme.

Ethical and moral issues. Participants viewed the pilot study as being riddled with ethical and moral tensions. Joy raised concerns about testing people living in poverty, stating, "We're not working with plants or [...], you know? We're working with actual peoples' lives." For others, the pilot study was seen as an extension of moral policing and surveillance. As Dale stated:

But they're not testing basic income. They're testing the poor. Because it comes back to the old moral assumptions, you know? If you give people a bit more money, will they spend it on drink or will they go to school?

As a social assistance recipient herself, Lucy questioned the fairness of the study, asking "Who's to say that this is fair to pick these people and not these people, you know?" In addition, Joy and Lucy both raised objection to the inclusion of a control group expected to not receive the basic income for the duration of the pilot study. 
Participation in the pilot study was often viewed and referred to as gamble. Several of the participants questioned the ethical nature of providing a temporary income increase to social assistance recipients with no guarantee that those benefits rates would be adopted across the province after the completion of the pilot. Others raised concern and uncertainty about whether the pilot study participants would have access to pre-existing social assistance benefits, such as allowances for special diets and assistive devices, or access to a case worker.

Later in the discussion, Dale interrogated the need to conduct a pilot study at all. Referring to the mincome pilot study conducted in Canada during the 1970s, Dale stated:

But there's no question, and that's the....to me, going all the way back to Dauphine, Manitoba and all this and they talk about these pilots, I mean there's no doubt that if you give people some extra money that are in poverty they're going to be somewhat better off.... People are very poor and you make them a bit less poor, the result is they're a bit better off!

This reflection raises an important ethical concern considering that a hallmark of securing approval from institutional research ethics board involves successfully arguing that a research project will produce new data and fill gaps in the existing literature. Yet, as Joy stated, “...we already have years and years and years of this kind of research on what happens to people who are on OW and ODSP."

Communication and transparency. Participants expressed several frustrations regarding the Ontario government's communication and transparency practices. Catherine shared one story of contacting the provincial government's basic income network to confirm if pilot study participants would have access to a caseworker. However, as she shared, "And they said that they were going to get back to me; they weren't sure if that was actually accurate. But no one 
has gotten back to me." In response, Dale shared that despite a spokesperson from the basic income network stating on a radio program that participants would have access to caseworkers, that his anti-poverty group had viewed government briefings stating that pilot study participants would not have caseworker access. Similar discussions were had regarding pre-existing allowances for special diets and assistive devices.

Speaking about the Ontario government's public meetings and consultation process, Lucy also expressed frustrations, stating that "the summaries that we got back from each individual one they put on the internet, they put summaries out there, and none of them really reflected anything that we brought to the meetings..." In response, Bruce shared, "But like any of these government run consultations, you know, they are what they want them to be.” This dialogue was indicative of the group's overall skepticism of the pilot study

Congruence between theory and design. Along with being plagued with moral and ethical issues and poor communication and transparency practices, many of the participants expressed that the pilot study design harboured incongruences between theory and design.

One of the major areas of concern was the pilot study's condition that $50 \%$ of all income earned by participants receiving the basic income would be clawed back. As Joy stated, “...there's no basic income model that has just a 50\% claw back. That's not how it's supposed to work. I don't even know where they came up with that." In relation, Lucy questioned how the financial situations of pilot study participants were expected to meaningfully improve if earned income was clawed back. This conversation was crucial for highlighting the importance that focus group participants placed on the desire for a universal basic income model without the means-testing measures of current social assistance programs. 
In addition to the claw back, there was a unanimous consensus that the pilot study's basic income benefit rates were inadequate for reducing poverty. In reviewing both the pilot study rates and current social assistance rates, Ella reflected that, "But it's like comparable to the rates that we currently have, which are atrocious. Like you can't tell me anyone can live off that." Joy had similar thoughts, stating, "And 75\% of the [Low Income Measure] is like, you know, 'Yah! It's more money!', but it's still not enough money for people to live on. It doesn't accurately show a basic income, what it should be." Lucy raised concerns about the precedent being set by the pilot study rates. As she said, the provincial government is sending a clear message that "it's legal that you live under the line of poverty and you can starve...". Such reflections brought to light participants' overall belief that the pilot study would be ineffective at reducing poverty in meaningful way.

Political motivations. Focus group participants also shared a unanimous skepticism and distrust of the political motivations fueling the pilot study. Speaking on the comparison between current social assistance rates and the pilot study rates, Ella reflected that “...if you compare these numbers by-by-side it looks like an amazing improvement, right? And that's a huge win for the [Ontario] Liberals because it makes everyone think like they're doing this amazing job for the province, when realistically..." This reflection was shared across the board, with many of the focus group participants commenting on the pilot study as a form of political posturing.

For others, the pilot study was viewed as a strategy to curry political and public favour while simultaneously avoiding immediate and necessary changes to the current social assistance programs. As Dale shared:

I think, apart from the unknown long-term possibilities of a basic income, for the [Ontario] Liberals this whole thing is an amazing opportunity to delay doing 
anything...And for years they've maintained the low social assistance rates on the basis of consulting and saying 'We're about to do something. Don't worry; it's just around the corner.' Well, this has given them a whole new lease on life that can't be underestimated. Such reflections bring into question the current provincial government's commitment to social justice and poverty, highlighting participants concerns that the Ontario Liberals project a socially liberal agenda backed by fiscally conservative budgets.

In summarizing her frustrations with the pilot study design, Joy shared that, "I don't actually think that this, whatever this is, actually reflects what people actually said that they wanted. Again, like I said, they took everything and were like, 'Whatever's the worst!' and just took it." This statement was echoed by many others, suggesting that among frontline service providers, the basic income model proposed by the Ontario Liberal's is a conservative actualization of a once progressive idea.

\section{Conclusion}

From these findings, it is evident that the focus group participants viewed the concept of a basic income with both optimism and considerable skepticism. In exploring the ongoing threats of technological displacement and neoliberalism, these frontline service providers expressed doubt that a basic income could fully remedy the economic inequality inherent to a capitalist society. In addition, due to the overlapping forms of marginalization that exacerbate poverty, participants' responses demonstrated a desire for equal attention to be given to a wide range of poverty responses such as education and housing. Yet, for some of those providing frontline social services, the possibility of even modest increases to the current social assistance programs was viewed as both desirable yet hardly adequate for addressing the full breadth and depth of poverty. With respect to the Ontario government's basic income pilot study, participants were 
nearly unanimous in expressing significant frustrations over the ethics, communication and transparency, and theory behind the pilot study. This evidently fueled participants' suspicions regarding the provincial government's motivations behind the pilot study, signaling to many of the participants that the pilot study was yet another delay tactic to avoid immediate social assistance reform.

In the following chapter, the above findings will be further explored by revisiting the existing literature to link new and old knowledge alike. 


\section{Chapter 6. Discussion}

Exploring policy responses to the human made problem of poverty is not a simple task. This is largely due to the social, economic, and historic legacies that continue to perpetuate poverty even during a period of unprecedented wealth. As succinctly explained by the Government of Canada (2016), poverty "impacts individuals in different ways and to different degrees" (p.7.). The experience can look uniquely different from person-to person, ranging from short-term poverty due to a job loss, long-term poverty due to a mix of socioeconomic barriers, or more chronic and pervasive poverty that is passed down between parents and their children. Due to the varying ranges and depths of poverty, it is no wonder that focus group participants often expressed mixed and/or conflicting views on the appropriateness and effectiveness of basic income.

\section{Interpretation of the Results}

In their recent discussion paper on poverty reduction, the Government of Canada (2016) listed the following multiple dimensions of poverty: income; housing and homelessness; jobs, training and the workplace; higher education; heath; and mobility and equality of opportunity. Not surprising is that focus group participants spoke about all these facets of poverty, suggesting that frontline providers, including grassroots activists and people with lived experiences of living on low-incomes, are well informed and positioned to be leading the charge against poverty. Yet, a significant difference between frontline service providers and government policymakers emerged through this focus group, namely the sense of urgency for immediate action.

\section{Incrementalism, policy change, and structural social work. Many of the frustrations} expressed by the focus group reflect a public policy theory and model known as incrementalism. According to Lindblom (as cited in Hayes, 2006), policymakers are often faced with limited time 
and information, forcing them to enact policy changes based on incomplete information and limited consideration of alternative options. Through this process, policymakers focus their attention to a "manageable number of options, and do so in a way that screens out alternatives unlikely to be adopted" (Hayes, 2006, p. 17). In practice, this results in policymakers focusing on incremental adjustments that only differ marginally from existing policies.

The frustrations expressed by Joy that plenty of research on social assistance already exists and by Dale that the provincial government has been consulting on social assistance reforms for years is indicative of the policy concept of seriality. Hayes (2006) explained seriality as a never-ending policy process resulting from "the failure of a given policy to completely solve a problem" which then "merely gives rise to subsequent rounds of policy-making" (p. 20). The concept of seriality gives legitimacy to Dale's critique that a policy end-run to poverty and neoliberalism is simply not possible. Since poverty is a problem created by humans and, at present, our society is organized around the exploitation and exclusion of large segments of the population, there is a possibility that a basic income will become yet another pit-stop on the cycle of poverty reduction seriality.

Throughout analyzing the focus group data, especially conversations on the province's pilot study, it became evident to me that I significantly underestimated the value of understanding the various approaches that inform anti-poverty responses. Vibrant Communities for Canada (2013), a coalition of 13 cities across the country that were involved in creating a poverty reduction theory of change, argued that there is a considerable difference between poverty alleviation and poverty reduction. Whereas poverty alleviation efforts lessen the symptoms of living on a low-income, poverty reduction looks to tangibly reduce the number of people living in poverty. Although a poverty reduction approach is, in theory, more proactive at 
addressing the root causes of poverty, it is limited by assuming that only reduction and not elimination is possible.

Through analyzing the focus group data, it became apparent that the participants did not adhere to the poverty alleviation approach and that many of them viewed poverty reduction as a temporary fix to the ever-evolving problem of capitalism. Instead, many of the participants' views reflected a poverty eradication approach. According to the Social Planning Network of Ontario, a poverty eradication approach "means pursuing the lowest possible levels of poverty in the industrialized world, both in incidence and in depth" (Novick \& Clutterbuck, 2011, p.6). In addition, the approach focuses on the adequacy of living conditions as opposed to individualizing poverty as a personal failing.

It is important to note that the three approaches along this anti-poverty response spectrum are not inherently anti-capitalist. None of the approaches outwardly reject the current systems of labour, currency and trade, nor the political, economic, and cultural mechanisms that perpetuate them. As argued by De Gruyter (2015), basic income proponents rarely adopt a stance on whether current political and policy apparatuses can facilitate meaningful change to quell the root causes of socio-economic inequalities. Present day realities such as the anti-social profiteering perpetuated by the current system of labour (Cottey, 2014) and the relationship between election cycles and anti-poverty programs (Houtzager, 2008) are seldom considered.

The concept of incrementalism brings to light an important limitation of adopting a structural social work approach that relies too heavily on public policy as a mechanism for social change. As a theory and practice approach devoted to addressing immediate needs and the pursuit of social transformation (George, Coleman, \& Barnoff, 2010), achieving both these objectives may not be possible through the current architecture of social policy. While policy 
may arguably be well suited for addressing the immediate material needs of marginalized groups, its inability to allow for anything more than moderate change over an extended time period means that the potential for social transformation will always live somewhere in a distant future.

Social policy is not void of power, however. In fact, non-incremental policy change, for better or worse, can and does happen. Using American examples, Hayes (2006) cited welfare system reform and national health insurance proposals as examples for when non-incremental policy changes were advocated for. In Ontario, we have also had moments of nonincrementalism. For example, between 1995 and 2002 the provincial Progressive Conservatives under Mike Harris made sweeping funding cuts and policy changes to social assistance, education and healthcare (Ross, 2011). Although many factors will influence incrementalism, such as an elected party possessing fewer seats and requiring more buy-in from resistant opposition parties, other factors such as political will clearly play a central role in the pace of social policy implementation.

Intersectional poverty and welfare state policy. As mentioned in the findings chapter, intersectionality was an underexplored topic throughout the focus group. When asked to think about how race could exasperate the experience of poverty, participants paused, asked for clarification, and stated that they did not believe a basic income could address racism. As the lone researcher and focus group facilitator for this project, I want to acknowledge that this response was also a reflection of my own biases and shortcomings. This will be discussed further in the limitations section. However, the participants' response to this question acted as a catalyst for me to revisit the research on intersectional experiences of poverty to better understand why this question did not spark more discussion. 
As a group of white-presenting frontline service providers, our understandings of the root causes of poverty were no doubt biased towards certain structural barriers. These barriers, such as low-income or unemployment, are defined as "single-factor triggers" (Corus et al. 2016, p. 211) and are often centred in analyses and policy responses to poverty. The result is a knowledge and response gap in addressing how intersecting vulnerabilities amplify experiences of material deprivation.

I would argue that this gap also constrains our conceptualizations of deprivation. For example, food insecurity understood exclusively through an anti-poverty lens reduces the root cause to low-income, while the food sovereignty perspective takes a wider approach by taking into consideration intersectional issues such as the need for Indigenous Peoples to control their own food systems through traditional practices (Suschnigg, 2012). As a result, the anti-poverty perspective only understands deprivation in terms of limited financial access, while the food sovereignty approach understands deprivation to also include the limited capacity to enact processes of self-determination. Likewise, with the dominant and overarching anti-poverty lens rooted in single-factor triggers, the compounding effects on poverty of living with multiple marginalized identities are rendered invisible.

In reflecting on the focus group, it is my opinion that our discussions were the product of this dominant anti-poverty discourse that centres single-factor triggers. Despite being wellinformed and intentioned, it is clear that this discourse was front and centre throughout our analyses of a basic income. This can be understood from a deeper perspective by turning to the concept of whiteness. According to the concept, whiteness operates from a place of invisibility that positions white experiences as universal, natural, and normative (Brander Rasmussen, Klinenberg, Nexica, \& Wray, 2001). As a group of white presenting individuals engaged in anti- 
poverty work, it is virtually impossible that our conversations would go untouched by whiteness due to its pervasive nature. Moreover, despite my intentions to incorporate an intersectional analysis throughout the entirety of this research project, whiteness remains a default that I can too easily slip back into when under pressure, time constraints, and other numerous challenges.

Discussions during the focus group were not entirely void of an intersectional analysis, however. As Ella discussed, Indigenous Peoples in Northern Ontario face unequal access to primary and secondary education. A recent report from People for Education (2017) confirms this, stating that schools in rural and Northern Ontario continue to struggle with decreasing resources, hampering their abilities to provide enriched learning experiences. This has significant implications for Indigenous Peoples' social and economic mobility should limited opportunities in primary and secondary school result in the inability to meet increasingly competitive postsecondary admission requirements. Considering that an estimated $80 \%$ of new jobs will require some form of post-secondary education by 2031 (Miner, 2014), the education needs and economic situations of Indigenous Peoples clearly deserve urgent attention and action.

On the labour market front, Joy discussed the intersectional challenges faced by racialized job seekers who experience employer discrimination. Recent research indicates that employer discrimination based on race is a significant issue. According to a recent study conducted in Toronto, Asian-named job applicants have a 32.6\% lower rate of interview selection compared to Anglo-named applicants while those with all or some foreign experience have an even lower rate of securing an interview (Banerjee, Reitz, \& Oreopoulos, 2017). Likewise, another recent study conducted in Toronto indicated that racialized immigrant and refugee women struggle with underemployment, exploitative employers, and intergenerational cycles of poverty related to precarious immigration statuses, language barriers, and challenges 
with their foreign experience and credentials not being recognized by Canadian employers ( $\mathrm{Ng}$ et al., 2016).

The intersectional experiences of poverty faced by Indigenous Peoples, Asian-named job applicants, and racialized immigrant and refugee women speak to a multitude of social and economic issues. Colonization, racism, immigration law, the rise of precarious employment, lack of access to education and social capital, and neoliberalism are just a short list of some of these issues compounding these unique groups' experiences of poverty. As a result, a single policy response, such as a basic income, to the single-factor trigger of low-income is clearly inadequate for addressing the full range of issues that influence intersectional experiences of poverty.

In a critique of advocacy efforts to return to the pre-1980 welfare state, Bernhardt (2015) argued that proponents often fall into a trap of overlooking the historical and structural ways in which marginalized communities, specifically women and racialized people, were excluded from the labour market to live on low-incomes and unequal pay. Furthermore, Bernhardt (2015) argued that the glorification of the postwar Keynesian welfare state disregards the reality that such policies were implemented to "complement existing market structures and never endeavored to challenge capitalist racialized hierarchies" (p.11). If implemented on its own, there is little to suggest that a basic income would function any differently to unsettle the current capitalist racialized hierarchy.

Bernhardt's critique of welfare state policies posits an important question. If a basic income is ill-equipped to address the range of intersectional barriers related to poverty, then is implementing the policy even worth the time and resources? The answer to such a big question is not simple. As Carniol (1992) argued, there are several different types of political change from a structural social work perspective. These forms of change include progressive shifts that 
dismantle privileges, regressive shifts that expand privileges for a select group of elites, and shifts that appear to be progressive on the surface and claim to weaken the consolidation of privilege while ultimately expanding it. As expressed by many participants, a basic income, at present, has the potential to go in any of these directions. Yet, Ella's comments regarding the immediate impact a basic income could have on her service users' wellbeing acts as a powerful reminder of the day-to-day material deprivation experienced by low-income people. Critical analysis, while powerful and valuable, does not put food on tables or house people experiencing homelessness. Furthermore, as a process of intellect that often has a limited reach beyond the confounds of post-secondary campuses and activism circles, critical analysis may, at times, contribute to incrementalism more so than it does to inspiring immediate social transformation. Considering this, critiques of a basic income, including the province's pilot study, should be tempered in the face of few politically viable alternatives.

Comparison of findings to existing literature. As mentioned in the research design chapter, there has only been one Canadian qualitative study published on a basic income. Conducted by Mulvale (2008), the author learned that his focus group participants also found the economic and welfare state status-quo as unacceptable. In addition, both our findings found that frontline service providers and anti-poverty activists held considerable interest in how a basic income could interact with existing social programs.

Although noted as not a predominant theme in his findings, Mulvale (2008) did state that many of his focus group participants viewed a basic income as "an ideological counterweight to neoliberal and related anti-welfare discourses" (p. 17). Several of the participants from my own focus group expressed the opposite opinion, sharing worries that a basic income could be used to advance a neoliberal agenda. This discrepancy is most likely explained by the increased 
popularity in the concept of a basic income. As Catherine discussed during the focus group, some conservative politicians are now promoting basic income as a way to cut back government spending on social services. Between Mulvale's study and my own, basic income has now become a politically malleability idea that, as referred to by Bruce, is increasingly nebulous in its definition and intended purpose.

\section{Implications for Service Users, Practitioners, and Policymakers}

The results from this research project generated several implications worth considering. For Ontarians living in poverty, participants' reflections about the moral and ethical dilemma of researching the process and results of temporarily improving low-income individuals' financial circumstances holds significance. From a surface level analysis, the province's pilot study may appear like a significant step towards a basic income becoming a reality. However, the very notion that pilot studies are even necessary indicates that the provincial government is not fully committed to abandoning the moral policing of previous social assistance models.

For social work practitioners, the participants' reflections on the potential manipulation of a basic income to accelerate neoliberalism signifies the future possibility of the profession becoming even more precarious. With many social work jobs already characterized as relief, part-time, and/or temporary contracts, there is plausibility that a basic income will be used to justify the need for a smaller workforce within social services. This may be especially true for social assistance caseworkers. Although purely speculative at this time, this potential shift may also increase barriers to entry into the profession for new practitioners as the number of qualified candidates increasingly outweighs the number of new job openings. 
For social work practitioners working frontline positions, a basic income may also have positive outcomes. For example, even with the moderate increases in social assistance rates proposed by the pilot study, social workers in housing may find service users' options increase in terms of securing affordable and safe housing. In addition, frontline social work practitioners may find themselves spending less time referring service users to food banks, meal programs, clothing services, shelters, and other services aimed at meeting immediate material needs. In addition, as discussed in the literature review, social work practitioners may also witness increased physical and mental health outcomes among their service users.

For social policymakers, the findings from this study suggest that there is significant frustration, displeasure, anger, mistrust, and an overall lack of support among frontline service providers and anti-poverty activists with respect to the province's basic income pilot study and the associated model. Additionally, the findings made clear the disconnection between frontline service provides' sense of urgency and the incrementalism enacted by policymakers and politicians. For the participants interviewed, the pilot study was viewed as a public relations stunt to salvage the current provincial government's alarmingly low approval ratings. Should these sentiments be shared across a wider segment of frontline service providers and anti-poverty activists, there is a potential for significant pushback against the current government during the upcoming election cycle. As a result, policymakers working on the current basic income pilot study may find themselves as a driving force behind a push to elect a different political party.

\section{Implications for Anti-Oppressive Practice}

Social work is a profession with a long history of applying band aid solutions to structural issues of oppression (Baines, 2011). By doing so, the very social systems responsible for generating theses oppression remained virtually untouched. As a form of theory and practice, 
anti-oppression provides a more social justice oriented alternative rooted in analyses of the structural origins of social issues, the need to transform social work practice and the relationship between practitioners and service users', and the pursuit of radical social change (Healy, 2005). However, as argued by Ross (2011), a traditional binary between direct service and structural action has engendered a narrow understanding of the role each of these unique spheres can play in achieving this vision of radical social change.

Bringing together traditional frontline service providers (those often considered to be involved with direct service) and grassroots activists (those often considered to be involved with structural change activism) to discuss social assistance reform is not a benign task. This is especially true for low-income grassroots activists. Participating in a two-hour focus group with the very individuals that police and gate keep their access to resources no doubt harbours the potential to invoke feelings of vexation, resentment, and anger. Throughout the design and execution of this project, I attempted to regularly remind myself of this potential tension, knowing that I may be putting certain participants in an uncomfortable position. With this in mind, I moved forward with the format of bringing together frontline service providers and antipoverty activists in order to bridge the superficial divide between direct service and structural action.

As noted by Ross (2011), both direct service activism and structural activism possess strengths and limitations. However, both these approaches can and do "play an important role in building social justice as they both improve the quality and quantity of political, social, and civil rights..." (Ross, 2011, p. 255). In bringing together the multiple actors involved in direct service and structural activism, I believe the result has been a much more robust and critical understanding of the political, social, and civil rights nuances of a basic income. 
I believe bringing an intersectional analysis to poverty has also contributed to a more critical understanding of a basic income. Considering that a core value of anti-oppressive practice is recognizing multiple forms of oppression (Healy, 2005), exploring basic income from an anti-oppressive perspective must include some degree of intersectionality. As someone highly interested in policy responses to poverty, this research project has significantly expanded my own understanding of the harmful limitations embedded in adopting a single-trigger approach to anti-poverty policy and interventions. As stated elsewhere, I cannot emphasis enough that this project's intersectional analysis is incomplete and requires ongoing theorizing and investigation to fully unearth the complexities between welfare state policies and intersectional experiences of poverty.

\section{Research Evaluation}

Authors such as Creswell (2013) and Lincoln and Guba (1985) advocate for a thorough and methodical approach to qualitative research evaluation. For Lincoln and Guba (1985), a strong evaluation ensures the trustworthiness of the research. These authors, among others, offer their own intricate versions of qualitative research evaluation, calling on researchers to comment on technical areas such as generalizability, audit trails, and referential adequacy.

As a graduate researcher educated in postmodern and post-structural thought, I question the need to adopt such standardized approaches to qualitative research evaluation. According to Rolfe (2006), qualitative research is simply too diverse to categorize and evaluate through a generic set of protocols. Despite also rejecting the positivist measures of rigour and validity, Strega (2005) argued that it is still necessary to provide readers with some criteria "to make connections between our analyses and the worlds, texts, people, and experiences that we write 
about" (p. 228). To accomplish this, Strega offered the following criteria for assessing research that draws on post-structural elements

- the political implications and usefulness of the research with respect to anti-oppressive politics for marginalized communities;

- speaking truth to power in accessible languages and formats; and

- measuring the extent to which the author(s) have been reflexive in exploring and acknowledging their own complicity in systems of oppression.

Below, I have adopted this criteria in an attempt to explore the limitations and strengths of this research study through a more post-structuralist orientation. Political implications with respect to anti-oppressive politics and practice will be discussed further in the proceeding section.

Limitations. This research is marked by multiple limitations.

First, the usefulness of this research to marginalized communities may be limited. As stated previously in the literature review chapter, grassroots groups primarily comprised of lowincome community members and social assistance recipients, such as OCAP (Clark, 2016) and Put Food in the Budget (Balkwill, 2016), have been highly vocal in expressing many of the same arguments discussed in the findings section. Additionally, labour unions representing frontline social service providers, such as CUPE (2017), have also been vocal in expressing their own concerns on a basic income and the Ontario government's pilot study. As a result, the novelty and credit of the research findings from this study should be reserved for those community activists and frontline providers who have been expressing their beliefs and concerns long before the introduction of this study.

Second, this project also suffered from time constraints that exist within the structure of completing a graduate research project, which undoubtedly resulted in a rushed data collection, 
analysis, and interpretation process. In order to speed up the latter half of the research process, member checking was not provided as an option to the participants. Considering this expedited process, the findings in this paper may present incomplete or inaccurate representations of participants' views and beliefs. This has important implications for the criteria of speaking truth to power in that participants' ability to exercise this practice was limited due to the lack of member checking, shifting the balance of power almost entirely into my hands as the sole researcher of this study.

Third and lastly, the results are likely hindered by a lack of racial diversity among myself and the focus group participants. Speaking on the need for poverty researchers to include an intersectional approach to their work, Corus et al. (2016) wrote that an "intersectional lens should resonate in all aspects of a research program for truly transformative analysis and meaningful impact" (p. 211). The authors go on to explain that this can be accomplished by refining research goals and questions, incorporating intersectionality into theoretical orientations, and being mindful of diversity throughout sample selection. Returning to my research question, I realized that I never defined for myself, the project, or the focus group participants who I understood to be the province's most economically marginalized. During recruitment, my idea of diversity was skewed towards securing any individual with lived experiences of poverty rather than those with intersectional experiences of poverty, including racialized participants. Due to these shortcomings, intersectionality became an additive aspect rather than a vocal anchoring point.

In retrospect, one of the reasons why I believe the focus group lacked an in-depth conversation around intersectional experiences of poverty is because I did not prepare the participants for such a conversation. Participants did not receive the question guide from me 
prior to the focus group, meaning that they could only prepare for the focus group by referring to the recruitment materials. Intersectionality was not mentioned throughout any of the recruitment materials; therefore, participants were provided with no indication that we would be discussing the connections between intersectional experiences of poverty and basic income.

The lack of wording around intersectionality in the recruitment material may have also impacted who did and did not respond to the focus group invitations. For those frontline service providers and activists who are interested in intersectional experiences of poverty, participation in the focus group may not have been appealing because of this lack of wording.

As a result of these intersectional shortcomings, this research project has inarguably been implicated in maintaining a narrow and white/Euro-western understanding of the root causes of and solutions to poverty. Therefore, this project leaves a significant research gap in understanding the complexities between poverty, race, other forms of oppression, and a basic income.

Strengths. In light of the limitations of this study, there are several strengths that I believe act as counterweights in other aspects of the research process.

Many low-income families and individuals experience material and financial barriers to participating in research (Schnirer \& Stack-Cutler, 2012). To mediate this, I included in my original research ethics board (REB) application that I would offer a range of incentives, including gift cards, transit tokens, a light dinner, and childminding. In their initial round of feedback, the REB stated that they would not endorse a graduate student paying for research expenses out-of-pocket. I responded to the chair, stating that I understood this and would remove the incentives from my research design. However, after receiving ethics approval, the exclusion of incentives felt unethical to me. After discussing with a colleague who encouraged me to stay 
true to my initial proposal, I responded back to the ethics board, stating that offering incentives was not negotiable. The REB eventually approved the inclusion of incentives and I moved forward with the research process. I believe this was crucial for ensuring an accessible format.

My primary recruitment goal was to secure 5-6 participants. However, the topic stimulated more interest than I had anticipated and I finished the recruitment phase with a total of 8 participants. Of these participants, three identified as having lived experiences of poverty. Unfortunately, two of these participants dropped the day of the focus group. However, I am proud to have stood by the need for incentives so that these individuals could consider and inquire about participation rather than immediately declining to participate due to financial barriers.

Another strength of this study was the emphasis placed on ensuring participants' views and opinions were properly understood. In the absence of member checking, I was mindful about the need to regularly repeat, paraphrase, and summarize participants' responses throughout the focus group. In doing so, I attempted to ensure that what was being recorded in the moment would accurately reflect participants' voices. During my own moments of uncertainty or confusion, I often asked participants to clarify or repeat their responses. In other instances, I made space for participants to make additional comments or backtrack to previous responses. Although these active listening techniques cannot fully replicate the results of member checking, I believe my efforts demonstrated a strong commitment to fully understanding the perspectives of each participant.

In addition to the above strengths, I have also remained committed to employing simple and accessible language throughout the entirety of the research process. This included ensuring recruitment material, interview guides, and the final paper were written with the limited use of 
academic jargon. Should I move forward with additional dissemination, I plan to remain committed to the use of accessible language by further reducing the use of language that individuals outside of academic social science environments would not be familiar with.

Lastly, throughout this study I have remained committed to not allowing my own beliefs regarding a basic income guide and bias the research process. At the beginning of this research project, I was a vocal advocate for a basic income. Prior to entering graduate school, I was heavily involved in a food security movement where basic income was regularly discussed, promoted, and advocated for. Yet, with the announcement of the provincial government's pilot study, I started to notice a more critical outcry emerge from grassroots activists. This led me to want to know more and to better understand these more critical perspectives. This curiosity pushed me to remain open-minded and flexible to these new ideas with neither fully adopting nor rejecting them. I believe this has done justice to my research question and the overall purpose of this study. 


\section{Chapter 7. Conclusion}

As a policy concept and political agenda item, basic income continues to gain increasing traction. Many researchers, politicians, and anti-poverty activists have been tireless in their efforts to see this concept evolve from theory to reality. Throughout this pursuit, basic income has been promoted with near universal acclaim. This momentum has significantly contributed to advancing dialogues on the inadequacies of the current welfare state and labour market. In the face of alarmingly low social assistance rates, increasing precarious employment, and the looming threat of technological displacement, these dialogues have no doubt been crucial to ensuring that those living in poverty are not left even further behind.

The findings from this study, although far from comprehensively conclusive, contribute to this dialogue in several ways.

Firstly, almost all Canadian research on a basic income has been conducted by public health and social policy researchers using quantitative methods. This study, from my knowledge, is only the second qualitative study in Canada to have been conducted through interviews with frontline service providers, anti-poverty activists, and individuals with lived experiences of poverty.

Secondly, the findings from this study contribute a more critical and nuanced perspective on basic income. The major findings regarding the policy concept, including the persistence and pervasiveness of economic inequality, the social complexities of poverty, and limited appropriateness and effectiveness of a basic income for addressing poverty, suggest that some frontline service providers view basic income with skepticism while others with cautious optimism. In addition, the findings suggest that frontline service providers view basic income as 
one of many necessary policy reforms desperately needed to quell the ongoing and negative effects of neoliberalism.

Thirdly, the findings from this study also question the necessity, ethics, and political motivations of conducting basic income pilot studies on low-income communities. This is particularly timely and crucial due to the proliferation of pilot studies planned within and outside of Canada.

It is hoped that these findings, in some small way, will contribute to the academic dialogue on basic income and encourage future researchers to endeavour on projects that look to complicate and deepen our collective understandings of this potentially revolutionary response to poverty. 


\section{Appendix A - Recruitment E-mail}

Hi

My name is Drew Silverthorn. I am a graduate student at Ryerson University in the School of Social Work. I am inviting you to take part in in a research study. This research is being done as part of my Master's project. My supervisor's name is Dr. Susan Preston, Associate Professor in the School of Social Work at Ryerson University. Dr. Susan Preston's contact information is 416-979-5000, ext. 6218 or susan.preston@ryerson.ca.

Recently, the Ontario government announced their plan to conduct a three-year basic income pilot study. The purpose of this pilot is to see if a basic income is a more effective response to poverty than current social assistance programs. Despite the growing body of literature on a basic income, few studies have looked at how frontline service providers who engage with lowincome individuals and families view this policy alternative. Additionally, almost no research looks at how anti-poverty or labour rights advocates view this policy alternative. Therefore, the goal of this research project is to to understand the concept of a basic income from the perspectives of these different groups.

To participate you need to meet the following criteria:

- Employed in a social services or community healthcare role (ie. social worker, nurse dietician, etc) where you provide services to low-income individuals, and/or

- Involved in anti-poverty, poverty alleviation, or labour rights advocacy/activism (ie. social assistance reform, housing rights, food security, worker's rights, etc.).

- Potential participants are asked to have been engaged in one of the above roles within the last six months. Additionally, participants are asked to have a general understanding of a basic income.

If you agree to volunteer you will be asked to participant in an audio-recorded focus group with 5-6 participants for two (2) hours. This focus group will be hosted at the Ryerson University campus. You will be asked to share your opinions about a basic income with the researcher and other participants. Questions will also be asked about the Ontario government's upcoming basic income pilot study.

In appreciation of your time, you will be offered two (2) TTC tokens and a $\$ 10$ grocery store gift card. Additionally, light refreshments will be provided at the focus group.

This research study has been reviewed and approved by the Ryerson University Research Ethics Board.

If you are interested in more information about the study, please find the attached consent form that details the research project in greater depth. If you have further questions and/or would like to participate in this study, please contact myself at andrew.silverthorn@ryerson.ca. 
Thank you for your time.

Drew Silverthorn

MSW Candidate, 2017

Ryerson University 


\section{Appendix B - Social Media Recruitment Text}

\section{PARTICIPANTS NEED FOR RESEARCH ON A BASIC INCOME POLICY:}

Are you a frontline service provider (ie. social worker, nurse, dietician, etc.) who works with low-income individuals and families and/or a community member involved in anti-poverty activism or labour rights?

If you answered yes to the above questions you are invited to volunteer in a study about understanding the opportunities and limitations of a basic income for addressing poverty in Ontario.

You will be asked to attend a two (2) hour focus group with 5 to 6 participants who are engaged in anti-poverty or poverty alleviation roles. The discussion will involve participants sharing their opinions on the strengths and weaknesses of a basic income policy for reducing poverty in Ontario. Participants will also be asked to discuss Ontario's recently announced basic income pilot study.

In appreciation of your time, you will be offered two (2) TTC tokens and a $\$ 10$ grocery store gift card. In addition, light refreshments will be provided at the focus group.

If you are interested in participating in this study or would like more information, please contact:

Drew Silverthorn

Master's of Social Work (MSW) student

Ryerson University

andrew.silverthorn@ryerson.ca

Please note this research is being conducted to partially fulfill the requirements of the above student's MSW degree. This research is being supervised by Dr. Susan Preston (416-979-5000, ext. 6218) and has been reviewed and approved by Ryerson University's Research Ethics Board. 


\section{Appendix C - Social Media Recruitment Material}

\section{PARTICIPANTS NEEDED FOR RESEARCH ON A BASIC INCOME POLICY}

ARE YOU

- A FRONTLINE SERVICE PROVIDER (IE. SOCIAL WORKER, NURSE, DIETICIAN, ETC.) TO LOW-INCOME

INDIVIDUALS AND/OR

- A COMMUNITY MEMBER INVOLVED IN ANTI-POVERTY ACTIVISM OR LABOUR RIGHTS ADVOCACY?

IF YOU ANSWERED YES TO THE ABOVE YOU ARE INVITED TO VOLUNTEER IN A STUDY ABOUT UNDERSTANDING THE OPPORTUNITIES AND LIMITATIONS OF A BASIC INCOME POLICY FOR ADDRESSING POVERTY IN ONTARIO. IN APPRECIATION OF YOUR TIME, YOU WILL BE PROVIDED WITH TWO (2) TTC TOKENS AND A $\$ 10$ GROCERY STORE GIFT CARD. 


\section{Appendix D - Consent Form}

\section{Ryerson University}

\section{Ryerson University \\ Consent Agreement}

You are being invited to take part in a research study because of your involvement in poverty reduction efforts. Please read this consent form so that you understand what your participation will involve. Before you consent to participate, please ask any questions to be sure you understand what your participation will involve.

\section{A BASIC INCOME FOR ALL? UNDERSTANDING THE BASIC INCOME CONCEPT FROM THE PERSPECTIVES OF COMMUNITY-BASED ADVOCATES}

\section{INVESTIGATORS}

This research study is being conducted by Andrew Silverthorn, a Master's of Social Work student at Ryerson University. The study is being supervised by Dr. Susan Preston, an Associate Professor in the School of Social Work at Ryerson University.

If you have any questions or concerns about the research, please feel free to contact:

Andrew Silverthorn

andrew.silverthorn@,ryerson.ca
Dr. Susan Preston

susan.preston@ryerson.ca

(416) 979-5000 ext. 6218

Ryerson University

99 Gerrard Street East

EPH 221, Eric Palin Hall

\section{PURPOSE OF THE STUDY}

The purpose of this research study is to understand the opinions of frontline service providers and anti-poverty and labour rights advocate who work for/on behalf of low-income individuals and families with respect to a basic income. These opinions will be used to better understand the strengths and limitations of a basic income policy for addressing poverty in Ontario.

The number of participants for this study will be from 5 to 6 individuals.

You who are eligible for this study if you are employed in a role where you provide frontline services to low-income families and individuals (i.e. social worker, nurse dietician, etc.), and/or are involved in anti-poverty, poverty alleviation, or labour rights advocacy/activism (i.e. social assistance reform, housing rights, food security, worker's rights, etc.). Potential participants are asked to have been engaged in one of these roles within the last six months. Additionally, you are asked to have a general understanding of a basic income. 
This research is being conducted in partial completion of the researcher's graduate degree. The results from this research will contribute to the researcher's major research paper (MRP).

\section{WHAT YOU WILL BE ASKED TO DO}

If you volunteer to participate in this study, you will be asked to do the following things:

- Review the following consent form in its entirety;

- Confirm your interest to participate in the study by contacting the researcher via e-mail;

- Attend a focus group at a to be determined location on the Ryerson University campus;

- Participant in an audio-recorded focus group for two (2) hours

- Share your opinions with the researcher and other participants about:

$\circ$ The strengths and limitations of a basic income policy for reducing poverty

- Your opinion about several aspects of the Ontario government's recently announced basic income pilot study (a brief overview of the pilot study will be provided at the focus group)

- Complete a survey at the focus group, providing the following information: e-mail address, ethnicity, gender/sex, income level, type of advocacy work, and role title;

- Maintain confidentiality after the interview process, including refraining from sharing the personal and professional identities of other research participants to individuals from outside the research project.

Should you wish to receive a final copy of the research paper, you can provide an e-mail address to the researcher at the focus group. This information will be collected by the survey mentioned before.

\section{POTENTIAL BENEFITS}

I cannot guarantee that you will receive any benefits from participating in this study. However, it is hoped that this research will help to diversify the perspectives regarding a basic income among individuals who read the final paper.

\section{COMPENSATION}

In appreciation of your time, you will be provided with two (2) TTC tokens and a $\$ 10$ grocery store gift card. If you wish to withdraw from the study during or after the focus group you will still receive the stated compensation.

\section{WHAT ARE THE POTENTIAL RISKS TO YOU AS A PARTICIPANT}

The potential for experiencing harm due to your participation in this research is low.

There is the possible risk that your identity and opinions will be shared outside of the research project by other participants. Your information will not be shared outside of this research project by the lead researcher or supervisor. However, neither the lead researcher nor supervisor can guarantee that other participants will not discuss your identity or opinions individuals from outside of the research project.

There is also the potential risk of experiencing emotional or psychological discomfort due to group interview dynamics. The researcher will attempt to ensure that the focus group is safe, 
comfortable, and welcoming to all participants. However, you may withdraw from the focus group at any point should you wish to.

Lastly, there is the risk that you may experience emotional or psychological discomfort triggered by discussions of personal experiences with poverty. The researcher will attempt to mediate this by directing the conversation away from in depth conversations about personal experiences of poverty. As mentioned above, should you feel uncomfortable or upset by the conversation, you may leave the focus group at any time.

Should you feel uncomfortable throughout any part of the research process, it is your right to withdraw, temporarily or permanently. In the event that you withdraw during the actual focus group, any contribution to the group interview that you made will remain part of the final data set as it will not be possible to remove individual responses captured during the audio recording of the focus group.

\section{CONFIDENTIALITY}

Signed paper consent forms, audio recordings of the focus group, and transcripts from the focus group audio recordings will all be collected. Signed consent forms will be kept in a secure locker in a locked room only accessible to other Master's of Social Work students. The audio recording from the focus group will be on a password protected audio recording device, which will later be transferred to a password protected computer and password protected USB. Only the researcher will have access to these devices and the associated data.

Should you wish to review the audio recording and the associated transcript, please contact the researcher as soon as possible so that a meeting can be arranged.

It is planned to use pseudonyms in the final paper. At the end of this form you will have the option of identifying a preferred pseudonym. You may leave this blank if you do not have a pseudonym preference.

Consent forms, audio recordings, and any documents containing information that can personally identify you will be destroyed after the final paper is submitted to the School of Social Work. This date will occur by mid-August 2017.

Digital transcripts from the focus group will be stripped of all identifying information and will be kept on a password protected USB for up to seven years in accordance with the Ontario College of Social Workers and Social Service Workers (OCSWSSW) record management policy. Transcripts will be kept for this time-period in case future data analysis opportunities emerge.

\section{VOLUNTARY PARTICIPATION AND WITHDRAWAL}

Participation in this study is completely voluntary. You can choose whether to be in this study or not. If any question makes you uncomfortable, you can skip that question. You may stop participating at any time and you will still be given the incentives and reimbursements described above. If you choose to stop participating during the actual, please keep in mind that your responses cannot be destroyed as it will not be possible to remove individual responses captured during the audio recording process. 
Your choice of whether or not to participate will not influence your future relations with Ryerson University or the investigators, Andrew Silverthorn and Dr. Susan Preston, involved in the research.

\section{QUESTIONS ABOUT THE STUDY}

If you have any questions about the research now, please ask. If you have questions later about the research, you may contact:

Andrew Silverthorn

andrew.silverthorn@,ryerson.ca

\author{
Dr. Susan Preston \\ susan.preston@ryerson.ca \\ (416) 979-5000 ext. 6218 \\ Ryerson University \\ 99 Gerrard Street East \\ EPH 221, Eric Palin Hall
}

This study has been reviewed by the Ryerson University Research Ethics Board. If you have questions regarding your rights as a participant in this study please contact:

Research Ethics Board

c/o Office of the Vice President, Research and Innovation

Ryerson University

350 Victoria Street

Toronto, ON M5B 2K3

416-979-5042

rebchair@ryerson.ca 


\section{Appendix E - Focus Group Interview Guide}

\section{Reminders:}

1. Please keep everything you hear in this focus group to yourself. You may discuss the general experience or what you learned with other people outside this group, but in order to ensure the confidentiality of everyone involved, I ask that you keep any information regarding other participants' names, roles, work or volunteer affiliations, and opinions to yourself.

2. Please feel free to ask for clarification or for more information any time throughout the focus group. It is important that you understand the questions being asked so that you can fully participant. With that said, it is important to remember that we all come from different backgrounds, experiences, and knowledge. Please be accepting and patient with other participants if they require clarification or more information.

3. When you are speaking about where you work or volunteer, please refrain from using the actual name of the organization. This is to ensure your confidentiality. If you accidently say the name of your organization or group it will be removed during the transcription process of the audio-recording. No documents that become publically available will share your real names or place or work or volunteer.

4. 5. My hope with this focus group is that it will be conversational and fluid as opposed to everyone answering the questions one at a time. I have chosen a focus group format in the hopes of stimulating debate. The objective is not to come to a consensus by the end, but rather to discuss differing viewpoints. You can also change your opinion at anytime.

5. If you need to exit the room at any time, please do so quietly. You are free to leave to use the washroom whenever you like.

6. Please go around and share your name, the type of work you do, and your role title. You may use a pseudonym for your name if you wish. 


\section{BI Focus Group Guide}

1. Please tell me what you know about the concept of a basic income, which is sometimes referred to as a guaranteed annual income or universal income.

2. This past year, the Government of Ontario announced their plan to launch basic income pilot study. The pilot study is to be carried out in three separate communities for a duration of three years. During the study period, eligible individuals will receive a benefit amount that will top of their incomes to $75 \%$ of the Low-income Measure After-Tax. Also during this time, the government will be collecting data related to participants' health, education, life decisions, administration and delivery, and other outcomes. These results will be used to assess the success of the pilot study and will ultimately be used to determine if a basic income program will replace the current social assistance system in Ontario.

Here is a copy of the proposed benefit rates for the pilot study (provide benefit rates sheet).

a) What are your thoughts about this pilot study? Do you support the pilot study - why or why not?

b) What are your opinions on the proposed benefit rates?

c) Most theoretical basis income models do not differentiate between a benefit rate for people living with disabilities and people out of work. What are your opinions on this? How might this relate to ideas of "deserving" and "undeserving" poor?

3. Theoretically, what kind of impact do you think a basic income could have on poverty reduction in Ontario? What about income inequality?

a) What gaps would remain unaddressed by a basic income?

b) Who might benefit and who might not benefit?

3. Not all populations experience poverty to the same degree. For example, Black and Indigenous communities experience the highest rates of food insecurity in Canada. How do you see a basic income impacting low-income communities that also struggle with other issues such as racism?

4. A common debate in the academic literature is whether governments should focus on guaranteeing jobs or guaranteeing income. What this means is that some people believe the government should focus on ensuring that there are enough quality jobs (ie. full-time, unionized, with benefits, etc.) for everyone, while others believe the government should focus on reforming social assistance by significantly increasing the benefit rates and making it available to more people. What are your thoughts on this?

5. Many high-profile business leaders support a basic income. This is especially prevalent among business leaders in the technology industry whose inventions are eliminating certain jobs. What is your opinion about these business leaders supporting a basic income? 
6. Several large labour unions have stated that they will not support a basic income that shrinks the welfare state and puts frontline service provider, such as social workers, out of work. What is your opinion on this?

- How do you think a basic income could impact your own advocacy and/or frontline work? 


\section{Appendix F - Research Ethics Board Approval}

REB 2017-044

Project Title: A Basic Income for All?: Understanding the Basic Income Concept from the Perspectives of Community-based Advocates

Dear Andrew Silverthorn,

Thank you very much for the submission of amendments for the above project. The Research Ethics Board has completed the review of your resubmission and the proposed amendments have been approved. This does not change the approval status nor the original approval date of the project.

Congratulations and best of luck with the project.

Please quote your REB file number (REB 2017-044) on future correspondence.

If you have any questions regarding your submission or the review process, please do not hesitate to get in touch with the Research Ethics Board (contact information below).

No research involving humans shall begin without the prior approval of the Research Ethics Board.

This is part of the permanent record respecting or associated with a research ethics application submitted to Ryerson University.

NOTE: This email account (rebchair@ryerson.ca) is monitored by multiple individuals. If you wish to contact a specific member of the Research Ethics Board, please do so directly.

Yours sincerely,

Zakiya Atcha, MSW

Research Ethics Co-Ordinator 


\section{References}

Acocella, I. (2012). The focus groups in social research: Advantages and disadvantages. Quality \& Quantity, 46(4), 1125-1136. doi:10.1007/s11135-011-9600-4

Baines, D. (2011). Social work activism amidst neoliberalism: A big, broad tent of activism. In D. Baines (Ed.), An Overview of anti-oppressive practice: Roots, theory, tensions (2nd ed.,pp. 1-24). Black Point, NS: Fernwood Publishing.

Balkwill, M. (2016, September 12). Let's break the cycle of endless studies and consultations. The Toronto Star. Retrieved March 28, 2017, from https://www.thestar.com/news/gta/2016/09/12/lets-break-the-cycle-of-endless-studies-andconsultations.html

Banerjee, R., Reitz, J., \& Oreopoulos, P. (2017). Do large employers treat racial minorities more fairly? A new analysis of Canadian field experiment data. Retrieved from University of Toronto, Munk School of Global Affairs website: http://www.hireimmigrants.ca/wpcontent/uploads/Final-Report-Which-employers-discriminate-Banerjee-Reitz-OreopoulosJanuary-25-2017.pdf

Baskin, C. (2016). Chapter fifteen: Taking back research. In Strong helpers' teachings: The value of Indigenous knowledges in the helping professions (2nd ed.) (pp. 321-354). Toronto: Canadian Scholars Press

Bernhardt, N. S. (2015). Racialized precarious employment and the inadequacies of the Canadian welfare state. SAGE Open, 5(2) doi:10.1177/2158244015575639 
Block, S., \& Galabuzi, G-E. (2011). Canada's colour coded labour market: The gap for racialized workers (Rep.). Retrieved from The Wellesley Institute website: http://www.wellesleyinstitute.com/publications/canadas-colour-coded-labour-market-thegap-for-racialized-workers/

Bourke, B. (2014). Positionality: Reflecting on the research process. The Qualitative Report, 19(33), 1-9. Retrieved from http://nsuworks.nova.edu/tqr/vol19/iss33/3

Brander Rasmussen, B., Klinenberg, E., Nexica, I. J., \& Wray, M. (2001). Introduction. In E. Klinenberg (Author) \& B. Brander Rasmussen, I. J. Nexica, \& M. Wray (Eds.), The making and unmaking of whiteness. (pp. 1-24). Durham, NC: Duke University Press.

Broadway, R., Cuff, K., \& Koebel, K. (2016) Designing a basic income for Canada. Retrieved from Queen's University Department of Economics website: http://qed.econ.queensu.ca/working_papers/papers/qed_wp_1371.pdf

Caelli, K., Ray, L., \& Mill, J. (2003). 'Clear as mud': Toward greater clarity in generic qualitative research. International Journal of Qualitative Methods, 2(2), 1-13. doi: $10.1177 / 160940690300200201$

Campaign 2000. (2016). Report card on child and family poverty in Ontario, 2015. Retrieved Family Service Toronto website: http://campaign2000.ca/wpcontent/uploads/2016/08/Ontario2015Report.pdf

Canadian Labour Congress. (2014). Underemployment is Canada's real labour market challenge: A profile of Canada's labour market. Retrieved from Canadian Labour Congress website: http://canadianlabour.ca/issues-research/underemployment-canadasreal-labour-market-challenge 
Canada Mortgage and Housing Corporation. (n.d.a). About affordable housing in Canada. Retrieved from https://www.cmhc-schl.gc.ca/en/inpr/afhoce/afhoce_021.cfm

Canadian Mortgage and Housing Corporation. (n.d.b). Core housing need (2011) - Ontario. Retrieved from Canadian Mortgage and Housing Corporation website: https://www03.cmhc-schl.gc.ca/hmiportal/en/\#Profile/35/2/Ontario

Canadian Union of Public Employees Ontario. (2017). Submission on the basic income pilot consultation. Retrieved from Canadian Union of Public Employees Ontario website: https://cupe.on.ca/submission-basic-income-pilot-consultation/

Canadian Women's Foundation. (2017). Fact sheet: Woman and poverty in Canada. Retrieved from Canadian Women's Foundation website: http://canadianwomen.org/facts-aboutwomen-and-poverty

Cantillon, S., \& McClean, C. (2016). Basic income guarantee: The gender impact within households. Journal of Sociology \& Social Welfare, 43(3), 97.

Caputo, R., Epstein, W., Stoesz, D., \& Thyer, B. (2015). Postmodernism: A dead end in social work epistemology. Journal of Social Work Education, 51(4), 638-647. doi:10.1080/10437797.2015.1076260

Carbado, D. W., Crenshaw, K. W., Mays, V. M., \& Tomlinson, B. (2013). Intersectionality: Mapping the movements of a theory. Du Bois Review, 10(2), 303-312. doi:10.1017/S1742058X13000349

Carniol, B. (1992). Structural social work: Maurice Moreau's challenge to social work practice. Journal of Progressive Human Services, 3(1), 1-20. 
Clarke, J. (2016, November 15). Ontario's austerity government sets basic income trap. The Bullet, 1330. Retrieved March 28, 2017, from http://www.socialistproject.ca/bullet/1330.php

Colour of Poverty - Colour of Change. (2011). 2011 Ontario social assistance review: Racialized communities' consultation report. Retrieved from Ontario Council of Agencies Serving Immigrants website: http://www.ocasi.org/downloads/SA\%20Consultations\%20Report\%20COPCOC\%202011.pdf

Corus, C., Saatcioglu, B., Kaufman-Scarborough, C., Blocker, C. P., Upadhyaya, S., \& Appau, S. (2016). Transforming poverty-related policy with intersectionality. Journal of Public Policy \& Marketing, 35(2), 211-222. doi:10.1509/jppm.15.141

Cottey, A. (2014). Technologies, culture, work, basic income and maximum income. AI \& Society, 29(2), 249-257. doi:10.1007/s00146-013-0480-0

Creswell, J. W. (2014). Research design: Qualitative, quantitative, and mixed methods approaches (4th ed.). Thousand Oaks, CA: SAGE Publications.

Creswell, J. W. (2013). Qualitative inquiry \& research design: Choosing among five approaches (3rd ed.). Thousand Oaks, CA: SAGE Publications.

Dachner, N., Gaetz, S., Poland, B., \& Tarasuk, V. (2009). An ethnographic study of meal programs for homeless and under-housed individuals in Toronto. Journal of Health Care for the Poor and Underserved, 20(3), 846-853. doi:10.1353/hpu.0.0167

Dahms, H. F. (2015). Which capital, which Marx? Basic income between mainstream economics, critical theory, and the logic of capital. Basic Income Studies, 10(1), 115-140. doi:10.1515/bis-2015-0016 
Daigneault, P., \& Béland, D. (2015). Introduction: Understanding welfare reform in the Canadian provinces. In P. Daigneault \& D. Béland (Eds.), Welfare reform in Canada (pp. 1-15). Toronto, ON: University of Toronto Press Higher Education.

Davison, K. M., Marshall-Fabien, G. L., \& Tecson, A. (2015). Association of moderate and severe food insecurity with suicidal ideation in adults: National survey data from three Canadian provinces. Social Psychiatry and Psychiatric Epidemiology, 50(6), 963-972. doi:10.1007/s00127-015-1018-1

Dempsey, D. (2008). The path to social justice goes through politics and economics. Journal of Policy Practice, 7(2-3), 94-105. doi:10.1080/15588740801937888

Elgarte, J. M. (2008). Basic income and the gendered division of labour. Basic Income Studies, 3(3), 4. doi:10.2202/1932-0183.1136

Emery, J. C. H., Fleisch, V. C., \& McIntyre, L. (2013). How a guaranteed annual income could put food banks out of business. Retrieved from University of Calgary, School of Public Policy website: http://www.policyschool.ca/wp-content/uploads/2016/03/emeryfoodbankfinal.pdf

Emery, J. C. H., \& Matheson, J. A. (2012). Should income transfers be targeted or universal? Insights from public pension influences on elderly mortality in Canada, 1921-1966. The Canadian Journal of Economics / Revue Canadienne d'Economique, 45(1), 247-269. doi:10.1111/j.1540-5982.2011.01694.x

Employment and Social Development Canada, Homelessness Partnering Strategy. (2016). Highlights of the National Shelter Survey, 2005 - 2014. Retrieved from the Employment and Social Development Canada website: https://www.canada.ca/en/employment-socialdevelopment/programs/communities/homelessness/reports-shelter-2014.html 
Employment and Social Development Canada, National Council of Welfare. (2012). Poverty profile: A snapshot of racialized poverty in Canada. Retrieved from the Employment and Social Development Canada website:

http://www.esdc.gc.ca/eng/communities/reports/poverty_profile/snapshot.pdf

Evans, P. M. (2007). (Not) taking account of precarious employment: Workfare policies and lone mothers in Ontario and the UK. Social Policy \& Administration, 41(1), 29-49.

Faulkner, S. S., \& Faulkner, C. A. (2014). Research methods for social workers: A practicebased approach (2nd ed.). Chicago, IL: Lyceum Books.

Fitzsimons, C. (2010). Professionalising community work and its implications for radical community education. Adult Learner: The Irish Journal of Adult and Community Education, 53-71.

Fook, J. (2012). Social work: A critical approach to practice (2nd ed.). London, England: SAGE Publications.

Forget, E. L. (2013). New questions, new data, old interventions: The health effects of a guaranteed annual income. Preventive Medicine, 57(6), 925-928. doi:10.1016/j.ypmed.2013.05.029

Friedman, M., \& Friedman, R. D. (2002). Capitalism and freedom: Fortieth anniversary edition. Chicago, IL: University of Chicago Press.

Gaetz, S., Donaldson, J., Richter, T., \& Gulliver, T. (2013). The state of homelessness in Canada: 2013. Toronto, ON: Canadian Homelessness Research Press.

George, P., Coleman, B., \& Barnoff, L. (2010). Stories from the field: Practicing structural social work in current times: Practitioners' use of creativity. Critical Social Work, 11(2). 
Gucciardi, E., Vogt, J. A., DeMelo, M., \& Stewart, D. E. (2009). Exploration of the relationship between household food insecurity and diabetes in Canada. Diabetes Care, 32(12), 22182224. doi: $10.2337 / \mathrm{dc} 09-0823$

Government of Canada, Employment and Social Development Canada. (2016). Towards a poverty reduction strategy: A discussion paper on poverty in Canada [Catalogue No. Em20-53/2016E-PDF]. Retrieved from https://www.canada.ca/en/employment-socialdevelopment/programs/poverty-reduction/discussion-paper.html\#h2.3

Harris, P. (2001). Towards a critical post-structuralism. Social Work Education, 20(3), 335-350. doi:10.1080/02615470120057424

Harvey, P. (2008). Is there a progressive alternative to conservative welfare reform? Georgetown Journal on Poverty Law \& Policy, 15(2), 157-208.

Hayes, M.T. (2006). Incrementalism and public policy. Lanham, MD: University Press of America.

Healy, K. (2005). Social work theories in context: Creating frameworks for practice. London, England: Palgrave Macmillan.

Hill Collins, P. (2015). Intersectionality's definitional dilemmas. Annual Review of Sociology, 41(1), 1-20. doi:10.1146/annurev-soc-073014-112142

Houtzager, P. P. (2007). The silent revolution in anti-poverty programmes: Minimum income guarantees in Brazil. IDS Bulletin, 38(6), 56-63. doi:10.1111/j.1759-5436.2007.tb00419.x

Human Resources and Skills Development Canada, Homelessness Partnering Secretariat. (2012). The National Shelter Study, 2005 - 2009: Emergency shelter use. [Catalogue No. HS6420/2012E-PDF]. Retrieved from http://www12.hrsdc.gc.ca 
Jamasi, Z. (2016). This is what working poverty looks like. OnPolicy. Retrieved March 18, 2017, from The Canadian Centre for Policy Alternatives website: https://www.policyalternatives.ca/publications/reports/onpolicy-ontarios-working-poor Kirkpatrick, S. I., McIntyre, L., \& Potestio, M. L. (2010). Child hunger and long-term adverse consequences for health. Archives of Pediatrics \& Adolescent Medicine, 164(8), 754-762. doi:10.1001/archpediatrics.2010.117

Kirkpatrick, S. I., \& Tarasuk, V. (2008). Food insecurity is associated with nutrient inadequacies among Canadian adults and adolescents. The Journal of Nutrition, 138(3), 604-613.

Kothari, C. R. (1990). Research methodology: An introduction. In Research methodology: Methods \& techniques (2nd ed., pp. 1-23). Daryaganj, New Delhi: New Age International.

Lightman, E., Mitchell, A., \& Herd, D. (2007). Returning to Ontario Works. Canadian Review of Social Policy/Revue Canadienne De Politique Sociale, 59, 20-43.

Lincoln, Y.S. \& Guba, E.G. (1985). Naturalistic inquiry. Newbury Park, CA: SAGE Publications.

Loopstra, R., \& Tarasuk, V. (2013). Perspectives on community gardens, community kitchens and the Good Food Box Program in a community-based sample of low-income families. Canadian Journal of Public Health / Revue Canadienne De Santé Publique, 104(1), 55-59.

Macdonald, D. (2016). A policymaker's guide to basic income (Rep.). Retrieved March 18, 2017, from Canadian Centre for Policy Alternatives website: https://www.policyalternatives.ca/publications/reports/policymakers-guide-basic-income McCall, L. (2005). The complexity of intersectionality. Signs, 30(3), 1771-1800. doi: $10.1086 / 426800$ 
McIntyre, L., Kwok, C., Emery, H. J. C., \& Dutton, D. J. (2016). Impact of a guaranteed annual income program on Canadian seniors' physical, mental and functional health. Canadian Journal of Public Health / Revue Canadienne De Santé Publique, 107(2), 176-182. doi:10.17269/cjph.107.5372

Merriam, S. B. (1988). Case study research in education: A qualitative approach. San Francisco, CA: Jossey-Bass.

Miner, R. (2014). The great Canadian skills mismatch: People without jobs, jobs without people and more. Retrieved from Miner Management Consultants website: http://www.minerandminer.ca/data/Miner_March_2014_final(2).pdf

Mulvale, J. P. (2008). Desperately seeking a new model of economic security for Canada: The basic income (BI) approach. Canadian Social Work, 10(1), 8-27.

Nash, J. C. (2008). Re-thinking intersectionality. Feminist Review, 89(1), 1-15. doi: $10.1057 /$ fr. 2008.4

Nelson, K., \& Fritzell, J. (2014). Welfare states and population health: The role of minimum income benefits for mortality. Social Science \& Medicine, 112, 63-71.

Ng, W., Sunder, A., Poole, J., Karpoche, B., Abdillahi, I., Arat-Koc, S., . . Galabuzi, G. (2016). A public health crisis in the making: The health impacts of precarious work on racialized refugee and immigrant women. Retrieved from Ryerson University website: http://www.ryerson.ca/content/dam/clmr/Publications/Final\%20Reports/Final\%20Report\% 20\%20A\%20Public\%20Health\%20Crisis\%20in\%20the\%20Making\%20The $\% 20$ Health $\% 2$ 0Impacts\%20of\%20Precarious\%20Work\%20on\%20Racialized\%20Refugee\%20and\%20I mmigrant $\% 20$ Women.pdf 
Novick, M. \& Clutterbuck, P. (2011). Humanity dignity for all: Working for a poverty free Ontario [Powerpoint slides]. Retrieved from: http://yrfn.ca/wpcontent/uploads/2011/08/PovFreeOnt_Presentation_BW.pdf

Ontario Disability Support Program Act, 1997, S.O. 1997, c. 25, Sched. B.

Ontario Ministry of Community and Social Services. (2016). Ontario moving forward with basic income pilot [Press release]. Retrieved from https://news.ontario.ca/mcss/en/2016/06/ontario-moving-forward-with-basic-incomepilot.html

Ontario Public Service Employees Union. (2017). Understanding basic income: An OPSEU position paper. Retrieved from Ontario Public Service Employees Union website: https://opseu.org/news/understanding-basic-income-opseu-position-paper\#toc11

Ontario Works Act, 1997, S.O. 1997, c. 25, Sched. A.

Parliament of Canada, Library of Parliament. (2008). Measuring poverty: A challenge for Canada. Retrieved from http://www.lop.parl.gc.ca/content/lop/researchpublications/prb0865-e.htm

People for Education. (2017). Competing priorities: Annual report on Ontario's publicly funded schools 2017. Retrieved from People for Education website: http://www.peopleforeducation.ca/wp-content/uploads/2017/06/P4E-annual-report2017.pdf

Prince Edward Island Legislative Assembly. (2017). Update on motion no. 83, universal basic income - 2017. Retrieved from http://www.assembly.pe.ca/docs/universalbasicincome_update.pdf 
Rabiee, F. (2004). Focus-group interview and data analysis. Proceedings of the Nutrition Society, 63(4), 655-660. doi:10.1079/PNS2004399

Raventós, D. (2007). Basic income: The material conditions of freedom. Ann Arbor, MI: Pluto Press.

Rolfe, G. (2006). Validity, trustworthiness and rigour: Quality and the idea of qualitative research. Journal of Advanced Nursing, 53(3), 304-310. doi:10.1111/j.13652648.2006.03727.x

Ross, M. (2011). Social work activism amidst neoliberalism: A big, broad tent of activism. In D. Baines (Ed.), Doing anti-oppressive practice: Social justice work (2nd ed., pp. 251-264). Black Point, NS: Fernwood Publishing.

Rountree, M. A., \& Pomeroy, E. C. (2010). Bridging the gaps among social justice, research, and practice. Social Work, 55(4), 293-295. doi:10.1093/sw/55.4.293

Schnirer, L., \& Stack-Cutler, H. (2012). Recruitment and engagement of low-income populations: Service provider and researcher perspectives. Retrieved from CommunityUniversity Partnership for the Study of Children, Youth, and Families website: http://www.cup.ualberta.ca/new-report-recruitment-and-engagement-of-low-incomepopulations

Segal, H. D. (2016, November 3). Finding a better way: A basic income pilot project for Ontario (Ontario, Ministry of Community and Social Services). Retrieved from https://files.ontario.ca/discussionpaper_nov3_english_final.pdf

Smooth, W. G. (2013). Intersectionality from theoretical framework to policy intervention. In W. R. Wilson (Ed.), SituatingiIntersectionality (pp. 11-41). New York, NY: Palgrave Macmillan. 
Statistics Canada. (n.d.). Low income statistics by age, sex and economic family type, Canada, provinces and selected census metropolitan areas (CMAs), annual. [CANSIM Table 2060041]. Retrieved from Statistics Canada website: http://www5.statcan.gc.ca/cansim/a26 Statistics Canada. (2017a). Labour force survey estimates (LFS), by sex and age group, seasonally adjusted and unadjusted monthly (persons unless otherwise noted). [CANSIM Table 282-0087]. Retrieved from http://www5.statcan.gc.ca/cansim/a26?id=2820087 Statistics Canada. (2017b). Labour force survey, December 2016. The Daily. Retrieved from http://www.statcan.gc.ca/daily-quotidien/170106/dq170106a-eng.htm

Statistics Canada. (2016). Low income lines: What they are and how they are created. [Catalogue number 75F0002M - No. 002]. Retrieved from Statistics Canada: http://www.statcan.gc.ca/pub/75f0002m/75f0002m2016002-eng.pdf

Stevens, H., \& Simpson, W. (2016). Towards a national universal basic income guarantee. Retrieved from University of Manitoba website: https://umanitoba.ca/media/Stevens_Simpson_notes.pdf

Strega, S. (2005). The view from the poststructural margins: Epistemology and methodology resistance. In L. Brown \& S. Strega (Eds.), Research as resistance: Critical, Indigenous, and anti-oppressive approaches (pp. 199-235). Toronto, ON: Canadian Scholars' Press.

Suschnigg, C. (2012). Food security? Some contradictions associated with corporate donations to Canada's food banks. In M. Koç, J. Sumner, \& A. Winson (Eds.), Critical perspectives in food studies (pp. 223-246) . Don Mills, ON: Oxford University Press.

Tarasuk, V. (2017). Implications of a basic income guarantee for household food insecurity (No. 24, Basic Income Guarantee Series, Rep.). Thunder Bay, ON: Northern Policy Institute. 
Tarasuk, V., Cheng, J., de Oliveira, C., Dachner, N., Gundersen, C., \& Kurdyak, P. (2015). Association between household food insecurity and annual health care costs. CMAJ: Canadian Medical Association Journal / Journal De l'Association Medicale Canadienne, 187(14), 429-436. doi:10.1503/cmaj.150234

Tarasuk, V., Dachner, N., Hamelin, A., Ostry, A., Williams, P., Bosckei, E., . . Raine, K. (2014). A survey of food bank operations in five Canadian cities. BMC Public Health, 14(1), 1234-1234. doi:10.1186/1471-2458-14-1234

Tarasuk, V., \& Dachner, N. (2009). The proliferation of charitable meal programs in Toronto. Canadian Public Policy / Analyse De Politiques, 35(4), 433-450. doi:10.3138/cpp.35.4.433

Tarasuk, V., \& Eakin, J. M. (2003). Charitable food assistance as symbolic gesture: An ethnographic study of food banks in Ontario. Social Science \& Medicine, 56(7), 15051515. doi:10.1016/S0277-9536(02)00152-1

Tarasuk, V., \& Eakin, J. M. (2005). Food assistance through "surplus” food: Insights from an ethnographic study of food bank work. Agriculture and Human Values, 22(2), 177-186. doi:10.1007/s10460-004-8277-X

Tarasuk, V, Mitchell, A, Dachner, N. (2016). Household food insecurity in Canada, 2014. Toronto: Research to identify policy options to reduce food insecurity (PROOF). Retrieved from PROOF website: http://proof.utoronto.ca

Thorne, S., Kirkham, S. R., \& MacDonald-Emes, J. (1997). Interpretive description: A noncategorical qualitative alternative for developing nursing knowledge. Research in Nursing \& Health, 20(2), 169-177. doi:10.1002/(SICI)1098-240X(199704)20:2<169::AIDNUR9>3.3.CO;2-B 
Tiessen, K. (2016, May). Ontario's social assistance poverty gap. Retrieved from Canadian Centre for Policy Alternatives - Ontario Office website: https://www.policyalternatives.ca/sites/default/files/uploads/publications/Ontario\%20Offic e/2016/05/CCPA\%20ON\%20Ontario's\%20social\%20assistance\%20poverty\%20gap.pdf

Vanderborght, Y. (2006). Why trade unions oppose basic income. Basic Income Studies, 1(1), 120. doi:10.2202/1932-0183.1002

Van Parijs, P. (1995). Real freedom for all: What (if anything) can justify capitalism? New York, NY: Oxford University Press. doi:10.1093/0198293577.001.0001

Van Parijs, P. (2004). Basic income: A simple and powerful idea for the twenty-first century. Politics \& Society, 32(1), 7-39. doi:10.1177/0032329203261095

Vibrant Communities of Canada. (2013). Collective impact approach. Retrieved from Vibrant Communities of Canada website: http://vibrantcanada.ca/files/vibrant_communities_canada_collective_impact_approach_0. pdf

Walby, S., Armstrong, J., \& Strid, S. (2012). Intersectionality: Multiple inequalities in social theory. Sociology, 46(2), 224-240. doi:10.1177/0038038511416164

Weinberg, M. (2008). Structural social work: A moral compass for ethics in practice. Critical Social Work, 9(1). Retrieved from http://www1.uwindsor.ca/criticalsocialwork/structuralsocial-work-a-moral-compass-for-ethics-in-practice

Weller, C. (2017, March 12). Universal basic income has support from some big names. Retrieved June 20, 2017, from https://www.weforum.org/agenda/2017/03/theseentrepreneurs-have-endorsed-universal-basic-income 
Wilson, D., \& Macdonald, D. (2010). The income gap between Aboriginal Peoples and the rest of Canada. Retrieved from Canadian Centre for Policy Alternatives website: https://www.policyalternatives.ca/publications/reports/income-gap-between-aboriginalpeoples-and-rest-canada 